\title{
Geological record of tsunami inundations in Pantano Morghella (south-eastern Sicily) both from near and far-field sources
}

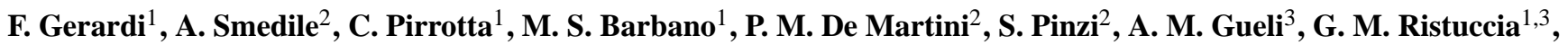 \\ G. Stella ${ }^{3}$, and S. O. Troja ${ }^{3}$ \\ ${ }^{1}$ Dipartimento di Scienze Geologiche, Università di Catania, Italy \\ ${ }^{2}$ Istituto Nazionale di Geofisica e Vulcanologia, Roma, Italy \\ ${ }^{3}$ PH3DRA laboratory, Dipartimento di Fisica ed Astronomia, Università di Catania, Italy \\ Correspondence to: F. Gerardi (f.gerardi@unict.it )
}

Received: 5 July 2011 - Revised: 18 November 2011 - Accepted: 7 December 2011 - Published: 26 April 2012

\begin{abstract}
Analysis of tsunami deposits from the Pantano Morghella area provided geological evidence for two inundations occurred along the south-eastern Ionian coast of Sicily. Pantano Morghella is a large pond characterised by a finegrained sedimentation indicating a low-energy depositional environment. Two anomalous yellow sandy layers found at different depths indicate the occurrence of high-energy marine inundations. We studied sedimentological and paleontological features of the anomalous deposits as well as their spatial distribution observing the following properties: different facies with respect to the local stratigraphic sequence; erosive bases, rip-up clasts and broken elements testifying violent deposition mechanisms; macro and micro fauna of marine environment; relatively constant thickness throughout most of the depositional zone with thinning at the distal end; large sand sheets that extend inland. These observations, jointly with their infrequency in the sedimentary record and the age indicating a fast deposition, provided strong evidence for tsunami inundations. Correlations between anomalous layers and historical tsunamis are supported by radiocarbon and OSL dating results. The younger deposit is likely due to the 1908 near-source tsunami, whereas the flooding of the oldest event is most likely associated with a far and large source, the Crete $365 \mathrm{AD}$ earthquake.
\end{abstract}

\section{Introduction}

The Mediterranean Sea has one of the longest records of tsunami occurrences; more than three hundred events have been reported since $1300 \mathrm{BC}$ originating in the Eastern Mediterranean, in southern Italy and in the southwest of Portugal (Soloviev et al., 2000). In general, historical accounts reporting information on tsunamis do not extend back in time far enough to provide reasonable estimates of the magnitude and frequency of past tsunamis at every location. In Italy, although exceptionally long, the historical dataset concerns the past millennium (Tinti et al., 2007 and references therein) and only for the last one hundred years the reports (e.g., Platania, 1909; Baratta, 1910) fully describe tsunami effects providing for each affected site both run-up values and limit of flooded areas, as well as information on the travel-time of the anomalous waves. Therefore, the geological evidence of tsunami related deposits could provide a longer record that can be extended back in time for the past 5-6 ka (e.g., Bourgeois, 2009 and references therein). The knowledge of the distribution and characteristics of paleotsunami deposits can help to answer questions about where a future tsunami can take place, how often it can occur and, only in favourable situations, how big it can be. The potential to extract a history of tsunami inundations from coastal sediments is not limited to source-bordering coasts, but also to far tsunamigenic sources (Atwater et al., 2005; Goff et al., 2010a). Therefore, looking for sedimentary record of tsunamis within the path of known tsunamis (near and far sources) could represent a useful tool for a complete local tsunami hazard assessment. Before the 2004 Indian Ocean tsunami, the literature on tsunami geology mainly dealt with Holocene tsunami sands deposited on coastal areas along seismically active continental margins and it was dominated by cases from Japan and Cascadia (northern California to southern British Columbia) (e.g., Bourgeois, 2009 and references therein). After the 2004 event, as a result of the increased awareness of worldwide coastal hazards, several geological studies provided the exact location, distribution and age range of inundations through the recognition and dating 


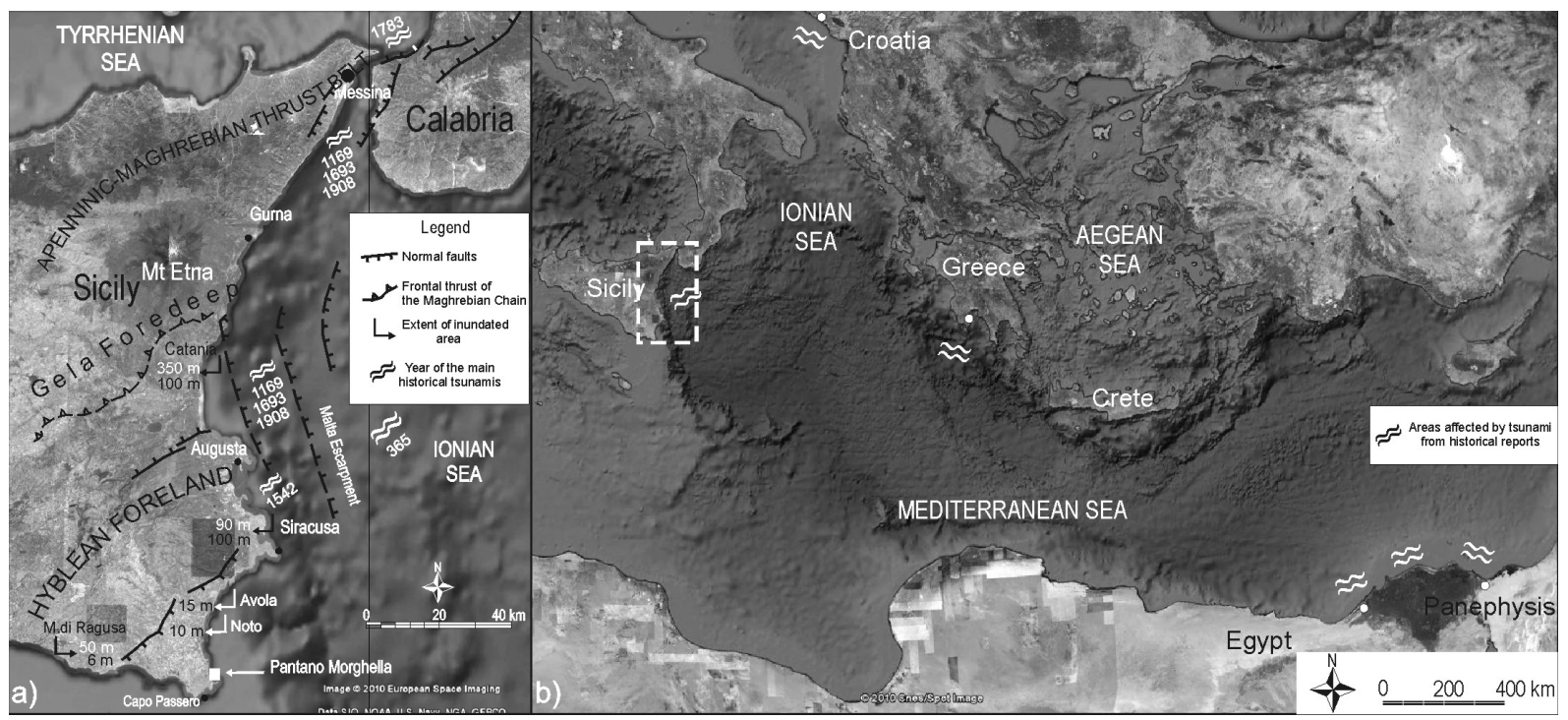

Fig. 1. (a) Google Earth map of Eastern Sicily showing the main structural domains and seismotectonic features (after Monaco et al., 2005); the wavy symbols with numbers indicate the year and affected areas of the main historical tsunamis affecting the eastern coast of Sicily; extent of inundated areas: white data for the 1693 tsunami and black for the 1908 tsunami (modified from Gerardi et al., 2008); (b) Google Earth map with localities affected by the 365 Crete tsunami according to historical information (after Guidoboni et al., 1994). Please note that the wavy symbols indicate generic areas affected by tsunamis from historical reports.

of tsunami deposits (e.g., Bourgeois et al., 2006; DomineyHowes, 2007; Goff et al., 2010b). Tsunami deposit research has also received attention in the Mediterranean area where population, infrastructures and economic activities are concentrated along the coasts (e.g., Ruiz et al., 2005; Mastronuzzi et al., 2007; Scheffers et al., 2008; Vött et al., 2009).

In Italy, tsunami geology began no more than $10 \mathrm{yr}$ ago. The first works describing geological evidence of tsunamis were focused on the Gargano coast (Adriatic Sea) (Gianfreda et al., 2001; De Martini et al., 2003) and Apulia coast (Ionian Sea) (Mastronuzzi and Sansò, 2000). Recently, tsunami deposits have been recognised in the NE tip of Sicily (Pantosti et al., 2008), in several sites along the eastern Sicilian coast (Barbano et al., 2009; De Martini et al., 2010; Scicchitano et al., 2010) and in the Augusta offshore (south-eastern Sicily) (Smedile et al., 2011). Other studies concern the transport and deposition of large boulders scattered along the coasts of Apulia (Mastronuzzi et al., 2007; Pignatelli et al., 2009) and along south-eastern Sicily (Schicchitano et al., 2007; Barbano et al., 2010).

However, given the variability in the nature of tsunami deposits, they are not uniquely identifiable, and other kinds of high energy deposits may share some of their features. Despite the abundant literature regarding diagnostic criteria for tsunami deposits, their distinction from storm and hurricane related layers remains a debated issue (Kortekaas and Dawson, 2007; Morton et al., 2007; Peters and Jaffe, 2010; Chagué-Goff et al., 2011).

In this paper, we present a study aimed at identifying geological evidence for tsunami inundations in south-eastern
Sicily providing useful tools (e.g., minimum inundation distance, frequency) to define local tsunami hazard. Since the deposition and preservation of tsunamiites are primarily due to the coastal geomorphologic setting and the available accommodation space, typical trap-sites (abandoned river channels, coastal lakes, lagoons and wetlands behind low barriers) (e.g., Atwater and Moore, 1992; Minoura et al., 1994; De Martini et al., 2003) have been looked at through a detailed geomorphologic study, aerial-photographs and satellite image interpretation and field surveys. In the southeastern tip of Sicily a site named Pantano Morghella (Fig. 1a for location), showing suitable morphologic characteristics for tsunami deposit search, was chosen and investigated. Our research involved, apart from historical studies on tsunamis and storms, geomorphologic surveys and coring campaigns, as well as some laboratory analyses (paleontological, X-ray). Radiocarbon and Optically Stimulated Luminescence (OSL) dating methods were used to constrain the age of the sediments, to derive sedimentation rates and to correlate potential tsunami deposits with historical events.

\section{Study area}

\subsection{Seismotectonic setting and historical tsunamis}

The study area is located along the southernmost Ionian coast of Sicily that constitutes the emerged part of the Hyblean foreland domain of the Apenninic-Maghrebian orogen (Lentini et al., 1994; Lentini et al., 2006). The Ionian coast 
is surrounded by seismogenic zones which produced large tsunamis in historical times (Tinti et al., 2007); in particular a north-south-trending fault zone (Fig. 1a), the Malta escarpment, which bounds the Hyblean plateaux to the east, plays an important role in the seismotectonic evolution of the area (Monaco et al., 2005). This fault system is considered the source of the strongest historical tsunamigenic earthquakes that affected south-eastern Sicily, such as the 1169 and 1693 events (Boschi et al., 2000); northernmost, in the Messina Strait on 28 December 1908 the strongest tsunamigenic Italian earthquake $\left(M_{\mathrm{w}}=7.1\right)$ of last century occurred (Pino et al., 2000). The Sicilian coastal areas also experienced the effects of tsunamis originated by distant sources, such as those belonging to the Aegean zone, e.g., the tsunami produced by the $365 \mathrm{AD}$ Crete earthquake (Fig. 1b) (Guidoboni et al., 1994; Stiros, 2001), and the event probably caused by the ca. 1600 BC Santorini plinian eruption (Dominey-Howes, 2004; De Martini et al., 2010; Smedile et al., 2011).

On the whole, during the last $2000 \mathrm{yr}$, at least 11 tsunamis affected the approximate $250 \mathrm{~km}$ long Ionian coast of Sicily as testified in the historical records (Soloviev et al., 2000; Tinti et al., 2007 and references therein).

\subsection{Pantano Morghella site}

The Pantano Morghella site is a flat wetland, $1.3 \mathrm{~km}$ long and $0.8 \mathrm{~km}$ wide (Fig. 2) that was partially used as salt-pans in the recent past. It is a pond surrounded by Upper Cretaceous lavas and volcanoclastic deposits to the south, by limestone as old as Late Cretaceous, to the north, by calcirudite, calcarenites and marls (Miocene and Eocene) and by Pliocene marls to the west (Lentini et al., 1986). In the eastern side Quaternary deposits, consisting of beach sands and $3 \mathrm{~m}$-high partially cemented fossil dunes, separate the wetland from the coast creating a restricted environment favourable for sedimentation and preservation of tsunami deposits. Nowadays, the only potential connection to the open coast is by means of a narrow ( $1 \mathrm{~m}$ large) channel that was cut through the dunes up to the beach for removing the water from the saltpans during the beginning of the 20th century (Marletta, 2002). The pond is usually partially submerged from October to July and it is dry for a short period after summer time. The area experienced modest $\left( \pm 0.2 \mathrm{~mm} \mathrm{yr}^{-1}\right)$ long-term vertical coastal movement (Ferranti et al., 2006) and very small $(-0.02$ and +0.07$)$ Holocene vertical rates (Antonioli et al., 2009).

\subsection{Storm inundation}

Tsunami deposits are not easily distinguishable from storm and hurricane deposits although their dynamics of transport and sedimentation are different. Because of their high-energy, tsunamis have a long wavelength (up to some $100 \mathrm{~km}$ ) and, therefore, their capacity to travel further inland

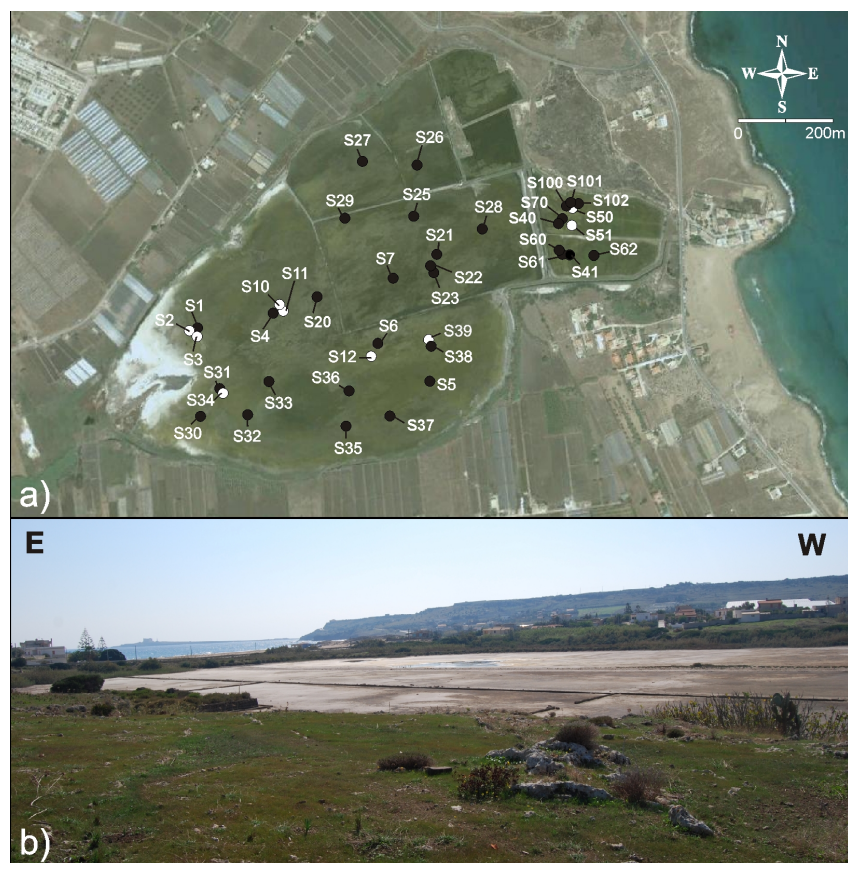

Fig. 2. (a) Satellite imagery of the study area; core locations are shown by white dots (engine cores) and black dots (hand cores); (b) photograph of the site (courtesy of Paolo Marco De Martini).

is major with respect to storms, characterised by shorter wavelengths (up to several $100 \mathrm{~m}$ ). Hence, storms are less able to transport and deposit material far inland with respect to tsunamis (Nanayama et al., 2000; Goff et al., 2004; Tuttle et al., 2004). Indeed, even in cases of hurricanes or typhoons sediment deposition, it is typically restricted to about 200 $250 \mathrm{~m}$ from the shore (Morton et al., 2007). Defining the storm deposition boundary in the study area can allow for the focusing of the tsunami field investigation far away from the expected storm-influenced area. Therefore, in order to mark out this latter area, we estimated the maximum inundation distance of extreme meteorological events (storms) of the Mediterranean Sea at Pantano Morghella. For this purpose, we analysed the anemometric and ondametric data (see also Barbano et al., 2010), recorded by the meteo-marine Catania station (the nearest to our site) belonging to the RON - Rete Ondametrica Nazionale (Italian Sea Wave Network, www.idromare.it) for the available period 1989-2006. Following the approach proposed by Vincent (1984), we estimated waves generated on restricted fetches (Seymour, 1977) to calculate the inundation distance of the strongest recorded storms (Table 1). The results show that the storm-influenced area at Pantano Morghella is restricted to approx. $60 \mathrm{~m}$ from the shore (Table 1). 
Table 1. Storm events with maximum wave height $\left(H_{0}\right)$ and peak period $\left(T_{0}\right)$ in deep water recorded by the Catania buoy and transposed data for Pantano Morghella site $\left(H_{T}\right.$ and $\left.T_{T}\right)$.

\begin{tabular}{|c|c|c|c|c|c|c|c|c|c|}
\hline \multirow[t]{2}{*}{ Date } & \multicolumn{3}{|c|}{$\begin{array}{l}\text { Wave data from } \\
\text { Catania buoy }\end{array}$} & \multicolumn{3}{|c|}{$\begin{array}{c}\text { Wave transposed } \\
\text { data at Pantano } \\
\text { Morghella (deep water) }\end{array}$} & \multicolumn{3}{|c|}{$\begin{array}{c}\text { Wave data and } \\
\text { flooding in Pantano } \\
\text { Morghella site }\end{array}$} \\
\hline & $\begin{array}{r}\text { Direction } \\
(\mathrm{N})\end{array}$ & $H_{0}$ & $T_{0}$ & $H_{T}$ & $T_{T}$ & $\begin{array}{r}L_{0} \\
(\mathrm{~m})\end{array}$ & $\begin{array}{r}\beta \\
\left({ }^{\circ}\right)\end{array}$ & $\begin{array}{l}H_{\mathrm{b}} \\
(\mathrm{m})\end{array}$ & $\begin{array}{r}X_{\max } \\
(\mathrm{m})\end{array}$ \\
\hline 31/03/1991 & $70^{\circ}$ & 5.1 & 9.1 & 5.6 & 9.7 & 147.6 & 1.15 & 5.8 & 15 \\
\hline 26/12/1992 & $94^{\circ}$ & 5.8 & 11.1 & 6.1 & 11.4 & 204.8 & & 6.7 & 20 \\
\hline 28/02/1996 & $104^{\circ}$ & 6.2 & 11.1 & 6.4 & 11.4 & 201.6 & & 6.9 & 20 \\
\hline $17 / 03 / 2003$ & $162^{\circ}$ & 3.8 & 13.3 & 5.1 & 16.1 & 404.4 & & 6.9 & 27 \\
\hline 04/10/2004 & $40^{\circ}$ & 4.1 & 28.6 & 4.5 & 31.4 & 1546.1 & & 8.8 & 60 \\
\hline 05/01/2005 & $129^{\circ}$ & 3.0 & 28.6 & 3.3 & 30.5 & 1454.1 & & 6.9 & 50 \\
\hline $12 / 01 / 2005$ & $119^{\circ}$ & 3.3 & 28.6 & 3.6 & 29.7 & 1383.5 & & 7.2 & 50 \\
\hline
\end{tabular}

$\beta$ is the average sea bottom slope from $-20 \mathrm{~m}$ depth to the shoreline as measured from the nautical maps of the Italian Marine Hydrographic Institute (Istituto Idrografico della Marina, 1999) at a scale of 1:100.000. Wave height $H_{T}$ and the peak period $T_{T}$ were computed following the transposition method and applying Vincent's (1984) equation at the investigated site. The estimated wave length in deep water $\left(L_{0}=g T^{2} / 2 \pi\right.$; Sarpkaya and Isaacson, 1981) and the wave height at breaking point $\left(H_{\mathrm{b}}\right)$ is determined with the Sunamura and Horikawa (1974) equation $\left(H_{\mathrm{b}} / H_{0}=(\tan \beta)^{0.2}\left(H_{0} / L_{0}\right)^{-0.25}\right) . X_{\max }$ is the maximum water flooding of the strongest storm waves in the study areas, obtained using the approach described by Barbano et al. (2010).

\section{Method}

At Pantano Morghella we carried out test coring campaigns by using hand auger equipment for an early reconstruction of sedimentary sequence and paleoenvironment. Preliminary stratigraphical and sedimentological descriptions together with photos of the core deposits were performed directly on the field. Once an interesting stratigraphic sequence was found, we executed coring of $1 \mathrm{~m}$ long samples (within specific PVC tubes) down to $5.80 \mathrm{~m}$ maximum of depth, by using the appropriate vibracoring device (gasoline powered percussion hammer). Every core was localized by GPS measurement in order to define the exact position with respect to the present shoreline. Totally, we took 31 hand and 9 engine exploratory cores covering a surface of about $0.350 \mathrm{~km}^{2}$, from $0.3 \mathrm{~km}$ up to a maximum distance of $1.2 \mathrm{~km}$ inland (Fig. 2a).

In the laboratory, PVC tubes were split lengthwise, photographed immediately after opening, logged to analyse depositional texture and sedimentary structures and described before collecting samples for paleontological analyses, as well as for isotopic and optically stimulated luminescence dating.

X-ray analyses were performed at ISMAR-CNR-Geologia Marina of Bologna on a few selected cores to put in evidence small-scale sedimentary structures (e.g., sharp contacts, convoluted layers, etc.) usually not clearly detectable through the standard stratigraphic analysis.

\subsection{Paleontological procedure}

Macrofaunal remains and grains were qualitatively analysed in terms of taphonomic and morphoscopic characteristics. For the identification of microfossil assemblages, foraminifera were investigated only on selected cores. Even if foraminifera, as a group have a cosmopolitan distribution and inhabit the entire marine realm, some individual taxa are well known to be restricted to specific environmental niches (for instance, marsh and brackish environments). This characteristic represents a useful instrument for palaeogeographic analysis and palaeoenvironmental reconstruction (e.g., Mamo et al., 2009). Moreover, due to their small size (between $\sim 100 \mu \mathrm{m}$ and $2 \mathrm{~cm}$ ), foraminifera possess both a high preservation potential within the sedimentary record after death and distinct diagnostic test shape. Samples were washed over $125 \mu \mathrm{m}$ and $63 \mu \mathrm{m}$ sieves in series and dried. The remaining sand fraction $>125 \mu \mathrm{m}$ was examined under the microscope for foraminifera and other biogenic remains. At least 100 benthic specimens were counted for each sample, where sufficient concentration was present, and they were identified with reference to Cimerman and Langer (1991), Sgarrella and Moncharmont Zei (1993). Selected species were photographed by using a JEOL JSM-6500F thermal field emission scanning microscope (FESEM). Differently from the benthic foraminifera, the planktonic assemblage was very poor and badly preserved; consequently it was counted simultaneously to the benthic assemblage, but examined only qualitatively.

To characterise the benthic foraminiferal assemblage structure, the Fisher alpha index (that calculates diversity based on the relationship between the number of species and the number of specimens in each assemblage) was estimated by using version 1.93 of the PAST (PAleontological STatistics) data analysis package (Hammer et al., 2001) only on selected cores. 
Table 2. Measured and calibrated ages (according to Calib REV5.0.2 by Stuiver and Reimer, 2005; $2 \sigma$ value) of the samples collected in the cores. Sample code indicates the core number and depth in $\mathrm{cm}$. The Table shows the calibrated ages resulting by using both the difference $\Delta R=124 \pm 60 \mathrm{yr}$ in reservoir age and the correction for marine samples (400 yr according to the calibration dataset marine04.14c, see Calib REV6.0). The last column shows the relative area under probability distribution (a value of 1.0 means that the age interval includes $100 \%$ probability).

\begin{tabular}{|c|c|c|c|c|c|c|c|}
\hline $\begin{array}{l}\text { Sample } \\
\text { code }\end{array}$ & $\begin{array}{l}\text { Sample } \\
\text { lab }\end{array}$ & Type & $\begin{array}{r}\text { Measured } \\
\text { Age BP }\end{array}$ & $\begin{array}{r}\delta^{13} \mathrm{C} \\
(\% o)\end{array}$ & $\begin{array}{r}\text { Calibrated age } \\
\Delta R\end{array}$ & $\begin{array}{r}\text { Calibrated age } \\
\text { (preferred) }\end{array}$ & $\begin{array}{l}\text { Probab. } \\
\text { Distrib. }\end{array}$ \\
\hline S12-69 & LTL4282A & Cerastoderma glaucum & $1989 \pm 45$ & $-6.2 \pm 0.4$ & 370-680 AD & $270-530 \mathrm{AD}$ & 1.00 \\
\hline S12-85 & LTL4283A & Cerastoderma glaucum & $1988 \pm 40$ & $-5.4 \pm 0.3$ & 380-680 AD & $280-520 \mathrm{AD}$ & 1.00 \\
\hline S12-97 & LTL4284A & Cerastoderma glaucum & $1927 \pm 50$ & $-3.8 \pm 0.5$ & 420-740 AD & $350-600 \mathrm{AD}$ & 1.00 \\
\hline $\mathrm{S} 12-312$ & LTL4285A & Cerastoderma glaucum & $4081 \pm 40$ & $-2.5 \pm 0.3$ & $2200-1780 \mathrm{BC}$ & 2300-2030 BC & 1.00 \\
\hline S39-142 & LTL4887A & Cerastoderma glaucum & $2096 \pm 50$ & $-9.3 \pm 0.5$ & 240-610 AD & 140-410 AD & 1.00 \\
\hline S39-415 & LTL4888A & Cerastoderma glaucum & $4746 \pm 50$ & $-9.1 \pm 0.2$ & $3110-2640$ BC & $3250-2900 \mathrm{BC}$ & 1.00 \\
\hline S51-26 & LTL4889A & Cerastoderma glaucum & $582 \pm 45$ & $-3.7 \pm 0.5$ & 1710-1950 AD & 1640-1880 AD & 1.00 \\
\hline S51-284 & LTL4903A & Cerastoderma glaucum & $3207 \pm 40$ & $-14.0 \pm 0.5$ & 1110-770 BC & 1200-930 BC & 1.00 \\
\hline
\end{tabular}

\subsection{Radiocarbon dating}

Radiocarbon dating by high-resolution mass spectrometry was performed at the facility of the CEDAD (CEntre for DAting and Diagnostics) Laboratories of the University of Salento (Lecce, Italy). All the dated samples are shells (always belonging to the Cerastoderma glaucum species) collected at different depths (max depth $4.15 \mathrm{~m}$ ) along the sampled cores. C14 derived data include measured and calibrated ages (according to Calib REV5.0.2 by Stuiver and Reimer, 2005) of the samples collected in the cores. We calibrated the radiocarbon measured ages by using both the reservoir correction for marine samples ( $400 \mathrm{yr}$ according to the calibration dataset marine 04.14c, see Calib REV6.0) and the difference $\Delta R=124 \pm 60 \mathrm{yr}$ in reservoir age to accommodate local effects (assuming water mixing between the Tyrrhenian and Ionian seas toward the Messina Strait, thanks to the NS oriented sea current affecting eastern Sicily), as commonly done for the northern part of eastern Sicily (De Martini et al., 2010; Smedile et al., 2011). Since, at the latitude of the Pantano Morghella site, superficial currents are too weak and seawater is unlikely mixed, we prefer the calibrated age obtained, considering only the reservoir correction for marine samples (Table 2).

\subsection{Optically Stimulated Luminescence dating}

Using the Optically Stimulated Luminescence (OSL) signals of quartz fractions contained in sedimentary deposits, it is possible to obtain their chronology. The related dating method is based on the assumption that the light-sensitive signal of these inclusions has been zeroed during last exposure to the sunlight, the "bleaching event". The age is, in this case, the time elapsed from this event to experimental OSL measurements (Huntley et al., 1985; Aitken, 1998). Previous studies showed the OSL usefulness to constrain the age of tsunamis (e.g., Huntley and Clague, 1996; Banerjee et al., 2001; Cunha et al., 2010). The methodology allows dating tsunami deposits considering their exposure to daylight by tidal currents, waves, wind, or bioturbation because the OSL signal is very quickly removed by light exposure.

In this paper, OSL was applied to achieve a correct imprint of the probable tsunami events both to narrow relatively large time-windows of radiocarbon and to date samples with insufficient organic material content.

All luminescence measurements were performed in the PH3DRA laboratory by using Ris $\varnothing$ TL/OSL DA15 reader (Bøtter-Jensen et al., 2003) equipped with a $1.48 \mathrm{GBq} \mathrm{Sr}-$ 90 beta source for irradiation. Quartz fraction purity separated was checked by the exposure to infrared (IR) light $(830 \pm 10 \mathrm{~nm})$. Stimulation with blue LEDs $(470 \pm 30 \mathrm{~nm})$ was performed at $125^{\circ} \mathrm{C}$ for $40 \mathrm{~s}$; the resulting OSL signal was detected through a $7.5 \mathrm{~mm}$ Hoya U-340 filter. The Single-Aliquot Regenerative-dose (SAR) protocol (Murray and Wintle, 2000, 2003) and double-SAR procedure (dSAR) (Roberts, 2007; Zhang and Zhou, 2007; Kim et al., 2009) were used for the ED determination on coarse grain quartz (CG) and polymineral fine grains (FG), respectively. The use of these different granulometry is, hereinafter, detailed.

Inductively Coupled Plasma mass spectrometry was used for $\mathrm{U}, \mathrm{Th}, \mathrm{K}$ and $\mathrm{Rb}$ content determination in order to estimate the dose rate contributions by using the conversion data cited by Adamiec and Aitken (1998). Corrections were made considering $\beta$ attenuation factors of Mejdahl (1979) and experimental water contents (Aitken, 1985). The cosmic-ray dose-rate contributions were calculated with reference to Prescott and Hutton (1994). According to the granulometry, the annual dose rate (DR) was estimated from the sum of contributions liable to the size of analysed grains (Aitken, 1985, 1998). The efficiency of alpha particles, $k$, was obtained using an external ${ }^{241}$ Am calibrated alpha source. Age is obtained by dividing the equivalent dose $\mathrm{ED}$ (measured in Gy) by the dose rate DR (expressed in Gy ka-1). 
Table 3. OSL dating results obtained on coarse grain (CG) and fine grain (FG) fractions extracted from the sandy depth of MOR-T02 and MOR-T01 layers.

\begin{tabular}{|c|c|c|c|c|c|c|c|c|}
\hline Layer & Core & Fraction & $\begin{array}{c}\varnothing \\
(\mu \mathrm{m})\end{array}$ & Procedure & $\begin{array}{l}\text { ED } \\
\text { Gy }\end{array}$ & $\begin{array}{c}\text { DR } \\
\mathrm{Gy} \mathrm{a}^{-1}\end{array}$ & $\begin{array}{l}\text { OSL age } \\
(2 \sigma) \text { a BP }\end{array}$ & $\begin{array}{l}\text { Date } \\
\mathrm{AD}\end{array}$ \\
\hline MOR-T02 & S39 & $\mathrm{CG}$ & $90-150$ & SAR & $2.58 \pm 0.04$ & $1.57 \pm 0.06$ & $1643 \pm 132$ & $368 \pm 132$ \\
\hline \multirow{3}{*}{ MOR-T01 } & $\mathrm{S} 100$ & FG & $2-11$ & dSAR & $0.38 \pm 0.06$ & $3.33 \pm 0.11$ & $113 \pm 38$ & $1897 \pm 38$ \\
\hline & S101 & FG & 2-11 & dSAR & $0.46 \pm 0.06$ & $4.19 \pm 0.14$ & $110 \pm 32$ & $1901 \pm 32$ \\
\hline & S102 & $\mathrm{CG}$ & $150-212$ & SAR & $0.20 \pm 0.01$ & $1.65 \pm 0.09$ & $118 \pm 18$ & $1893 \pm 18$ \\
\hline
\end{tabular}

The samples were collected by driving light-tight PVC tubes, sealed after the extraction with black tape. In the luminescence laboratory, the tubes were opened in subdued orange light and the outer parts of the core were used for DR analysis whereas the inner part, which was not exposed to light, was used for ED determination.

All samples were at first subjected to standard PH3DRA laboratory coarse grain protocol (Bianca et al., 2011) but the amount of this fraction was not always sufficient to guarantee an adequate statistic on aliquots with precise granulometry. In order to obtain a sufficient quantity of aliquots for OSL measurements, we were pressed to use both CG with different granulometry and $2-11 \mu \mathrm{m}$ FG fractions (Roberts and Wintle, 2001). Table 3 reports the dimensions of the grains used for OSL measurements.

For the CG fraction, in order to select appropriate preheat conditions for ED determination using SAR protocol, the preheat temperature plateau was conducted (Kiyak and Canel, 2006). Based on the results of the preheat tests, $10 \mathrm{~s} @ 180^{\circ} \mathrm{C}$ for the preheating of the regeneration dose, as well as the test dose, was chosen. The cycle of SAR protocol was repeated 6 times using regeneration doses from 0.2 to $2.5 \mathrm{~Gy}$ with a test dose of $0.2 \mathrm{~Gy}$ with a cut-heat at $160^{\circ} \mathrm{C}$. The integral of the first $0.8 \mathrm{~s}$ of the stimulation curve was used for ED determination, after subtracting the background derived from the last $3.5 \mathrm{~s}$ integral of the OSL signal.

The equivalent doses have been measured for polymineral FG fraction using d-SAR procedure. This protocol involves the exposure to infrared radiation in order to reduce the OSL contribution from feldspars. The signals used for dating, named [post-IR] OSL, were obtained after this first step on stimulation with blue light. The optimal preheat temperature for the analysed samples was chosen considering the results obtained working in the range $180-260^{\circ} \mathrm{C}$ for $10 \mathrm{~s}$. The [post-IR] OSL signals were recorded by 5 cycles using doses from 1 to $5 \mathrm{~Gy}$ with a test dose of $1 \mathrm{~Gy}$ at the same experimental parameters of CG fractions. Uncertainties taken into account in the ED include systematic errors in calibration of the beta sources $(3 \%)$ and random errors due to spread in results obtained on measured aliquots.
The DR values were corrected assuming that the water content prevailing throughout the burial time was $2 / 3$ of the measured saturation one (Cunha et al., 2010).

\section{Results}

\subsection{Stratigraphical analysis}

The core analysis revealed that the site stratigraphy is quite uniform and no relevant sedimentological changes were noticed. In the following, we will describe the stratigraphy of S3, S39 and S50 cores considered representative of the westward, central and eastward part of the site, respectively (Fig. 2a). To simplify the description, we decided to sketch the stratigraphy using lithostratigraphic units.

The S3 core was dug down to a $4.50 \mathrm{~m}$ depth and its stratigraphy consists of gray-brownish silty clay and clay silt alternation (named UNIT A) with shell fragments and vegetal remains from $4.50 \mathrm{~m}$ to $2.70 \mathrm{~m}$ of depth (Fig. 3a); from $2.70 \mathrm{~m}$ to $1.35 \mathrm{~m}$ of depth, the stratigraphy is characterised by gray clay with shell fragments, locally abundant, few whole gastropods and bivalves and vegetal remains (UNIT B). The clay is interrupted at $1.35 \mathrm{~m}$ of depth by $4 \mathrm{~cm}$ of a distinctive medium-coarse yellow sandy layer (UNIT C $=$ MOR-T02 in Fig. 3) with shell fragments (Fig. 3b). Above the sandy unit up to $0.90 \mathrm{~m}$ of depth, brown clay with few and scarce shell fragments (UNIT D) is recognised. On the top, the core contains a $0.70 \mathrm{~m}$ thick light gray silty clay and clayey silt (UNIT E) followed upwards by $30 \mathrm{~cm}$ of thick brownish soil. X-ray imaging performed on the S3 core proves that the stratigraphy is quite uniform and no relevant sedimentological changes, as well as presence of bioturbation, were observed; moreover it shows that UNIT C is characterised by a fining upward grain size and a sharp, possibly erosional, basal contact (Fig. 3c).

S39 is the deepest core dug in Pantano Morghella (Fig. 2a) and its stratigraphy shows the alternation of graybrownish silty clay and clayey silt (UNIT A) with shell fragments and vegetal remains from $5.80 \mathrm{~m}$ to $2.60 \mathrm{~m}$ of depth (Fig. 4a). Above the UNIT A, the core contains gray clay with shell fragments, locally abundant, few whole gastropods and bivalves and vegetal remains (UNIT B), 


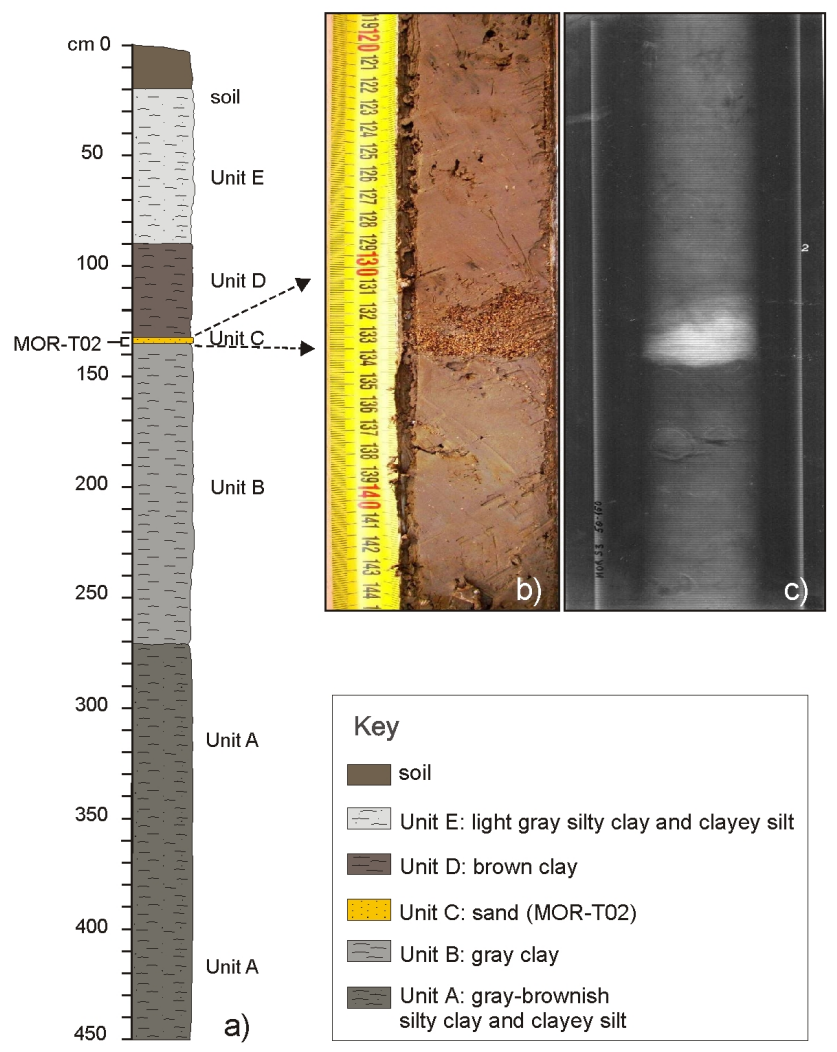

Fig. 3. (a) S3 core log representing the stratigraphy of the Pantano Morghella western side; (b) detail of the S3 core showing the sandy layer (UNIT C) within the silty clay; (c) X-ray film of the core.

followed by the distinctive medium-coarse yellow sandy layer (UNIT $\mathrm{C}=$ MOR-T02 in Fig. 4) with shell fragments characterising the stratigraphy at about $1.35 \mathrm{~m}$ depth (Fig. 4a); its thickness is about $10 \mathrm{~cm}$, it shows some clayey rip-up clasts (Fig. 4b) and it is followed by a $5 \mathrm{~cm}$ transitional layer made of sand and clay (UNIT C1). From $1.20 \mathrm{~m}$ to $1.10 \mathrm{~m}$ of depth brown clay with few and scarce shell fragments (UNIT D) is observed. It is followed by light gray silty clay and clayey silt of UNIT E above which $10 \mathrm{~cm}$ of thick brownish soil crops out.

The S50 core reaches $3.10 \mathrm{~m}$ of depth and it could be considered representative of the Pantano Morghella eastward part (Fig. 2a) that was partially used as salt pans in the recent past. In the stratigraphic sequence from the core bottom to $1.80 \mathrm{~m}$ of depth the gray clay of UNIT B is recognised (Fig. 5a), followed by the brown clay UNIT D up to $0.60 \mathrm{~m}$ of depth. The silty clay and clay of UNIT E characterises the core from $0.60 \mathrm{~m}$ to $0.07 \mathrm{~m}$ of depth; above UNIT E, we observe a $3 \mathrm{~cm}$ thick yellow sand with silty clay matrix (UNIT F $=$ MOR-T01 in Fig. 5) covered by a $4 \mathrm{~cm}$ thick brownish soil (Fig. 5b).

Summarizing, the sedimentological analysis performed on the core samples revealed that the pond is characterised by

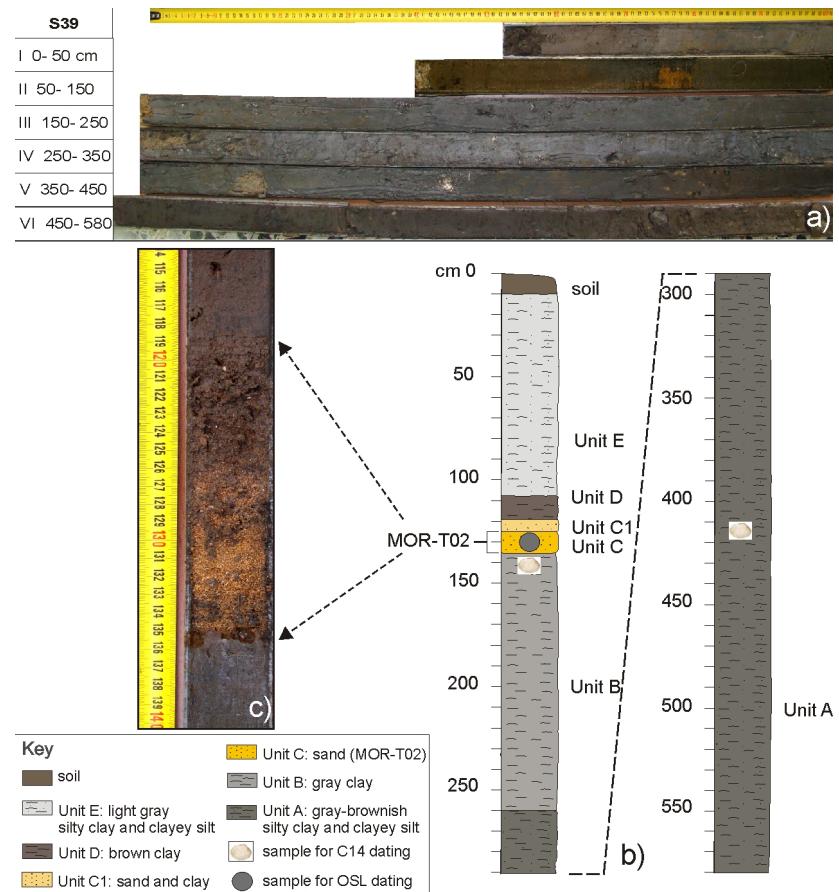

Fig. 4. (a) Photo of the S39 vibrocoring core collected at the Pantano Morghella. Core location is shown in Fig. 2a. Scale is in $\mathrm{cm}$. Roman numbers indicate $1 \mathrm{~m}$ cores from the top; cores II and VI are compressed. (b) S39 log representing stratigraphy of the Pantano Morghella central part; (c) core photo from $1.14 \mathrm{~m}$ to $1.40 \mathrm{~m}$ of depth. Please note the rip-up clasts in the sand level.

a fine-grained stratigraphic sequence dominated by clay and silty-clay deposits. Within this sequence, we recognised only two abrupt changes in grain size identified by the two coarse yellow sandy levels of UNIT C and UNIT F; given their different position in the stratigraphy, these units represent two distinctive anomalous layers identified thereafter as MORT02 and MOR-T01, respectively.

The MOR-T02 deposit was found in almost all the cores in the central part of the pond and it overlays the UNIT B in the stratigraphic sequence; the MOR-T02 is distributed almost continuously on the gentle topography and extends inland for at least 1200 metres. Moreover, its thickness decreases with the distance from the sea and varies between $24 \mathrm{~cm}$ in the central part ( $\mathrm{S} 20$ core) and $3 \mathrm{~cm}$ in the westernmost boundary (S2 core) of the pond (see Fig. 2a). In some cores (S10, S11, S12, S39) on the top of MOR-T02 deposit a transitional layer made of sand and clay was recognised (Fig. 4b), whereas in other cores (S4, S20, S31, S34) a thin and dark gray clayey sheet was observed on top of it.

The MOR-T01 deposit was detected in the cores dug in the easternmost sector of the pond (S40-41, S50-51, S6162 and S70) (Fig. 2a) and it overlays silty clay and clay of UNIT E within the stratigraphy; in some cores (S51, S60), it is followed by a $3-4 \mathrm{~cm}$ thick transitional layer made of clay and sand (UNIT F1 in Fig. 7), marking out the passage 

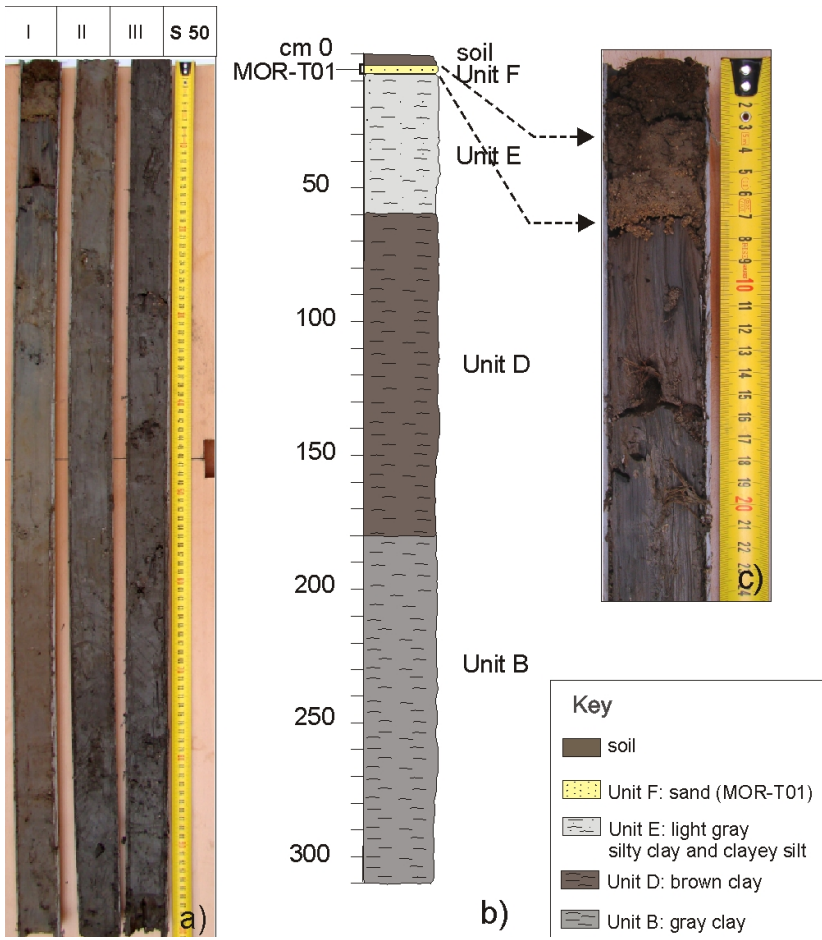

Fig. 5. (a) Photo of the S50 vibrocoring core collected at the Pantano Morghella. Core location is shown in Fig. 2a. Scale is in $\mathrm{cm}$. Roman numbers indicate $1 \mathrm{~m}$ cores from the top. (b) S50 log representing stratigraphy of the Pantano Morghella eastern part; (c) core photo from 0 to $24 \mathrm{~cm}$ of depth.

to the brownish soil. MOR-T01 shows a sharp basal contact, an inland extension of at least $380 \mathrm{~m}$ and variable thickness between 3 and $30 \mathrm{~cm}$. This difference in thickness can be explained only partially by the two distinct coring techniques adopted in this work (hand and engine coring) and it is likely related to the topographical variability at the time of the event.

Grain size of MOR-T02 and MOR-T01 layers, jointly with their fining-upward and the sharp/erosional basal contact provide strong evidence for a marked and sudden change within the low-energy environment of Pantano Morghella, suggesting the occurrence of at least two high-energy depositional events.

\subsection{Paleontological analysis}

On samples collected from some selected engine cores, quantitative foraminiferal analyses and macrofaunal observations were carried out. In order to show the paleoenvironment evolution of the western part of the Pantano Morghella we chose the $\mathrm{S} 12$ core $(3.50 \mathrm{~m}$ long) as representative of the overall study sequence (Figs. 2 and 6).

Starting from the bottom, the fine grained silty to clayey sequence is characterised by smooth carapax ostracods, charophyte gyrogonites and molluscs, both as fragments and as whole shells (mainly Cerastoderma glaucum and Hydrobia spp.) indicating a lagoonal paleoenvironment (euryaline and eurythermal biocenosis in brackish waters sensu Peres and Picard, 1964). This interpretation is also supported by the presence of oligothipic foraminiferal assemblage (see Haynesina germanica and Ammonia tepida in Fig. 6) typical of lagoonal conditions (see Murray, 2006 and references therein).

Reaching the bottom of the sandy layer (MOR-T02), a distinct increased diversity in the foraminiferal assemblage is evident, also highlighted by the Fisher alpha index (Fig. 6).

This coarse interval contains abundant shell debris made of molluscs, sea urchins, corals, sponge spicules and bryozoa. Although the species found in the samples from the fine-grained unit below are still present, numerous additional open marine benthic species appear. In fact, Quinqueloculina spp. and Elphidium crispum are well represented, together with several other taxa (in most cases epiphytic inhabitants of the near shore), such as, Cibicides lobatulus, Miliolinella spp., Nubecularia lucifuga, Rosalina spp., and Triloculina spp. Many other species are present with only one specimen per samples (lumped in the group named others, plot in Fig. 6) like Asterigerinata mamilla, Miniacina Minacea, Peneroplis pertusus Sorites orbicularis typical of sublittoral environment, and Cibicides refulgens, Melonis barleeanum, Planulina ariminensis, Textularia sp. coming from the outershelf depth (Murray, 2006). In general, the tests of the foraminifera found in the sandy interval are fairly well preserved except for some of them that are rather smooth and sometimes difficult to classify even at genus level (see the plot named undetermined specimens in Fig. 6).

Furthermore, planktonic foraminifera, showing a clear increment in correspondence to the sandy layer MOR-T02, are very poorly preserved, thus interpreted as reworked, and were observed and classified only rarely at specific level. Moreover, differently from the fine-grained sediments, the sandy samples are rich of smoothed yellowish bioclastic clasts recognised as "ghost shells" (see Fig 7c). Thus, in the sandy interval both the mixing of different lagoonal (autochthonous) and marine (allochthonous) foraminiferal assemblages and a general higher number of species are well documented (Fig. 6).

Above the MOR-T02 layer, the uppermost part of the core up to the surface appears characterised by fine-grained sediments dominated by the same lagoonal assemblage found in all the core sediments but the sandy interval (Fig. 6).

For the eastern sector of Pantano Morghella, we chose the S51 core $(3.10 \mathrm{~m}$ long) as representative of the studied sequence all around. Similarly to the western sector, the benthic foraminifera assemblage shows an abrupt change in correspondence to the sandy interval (Fig. 7a). In fact, considering as autochthonous the assemblage typical of lagoonal environment and allochthonous the left species coming from the sub-littoral and littoral paleoenvironment, we can notice 


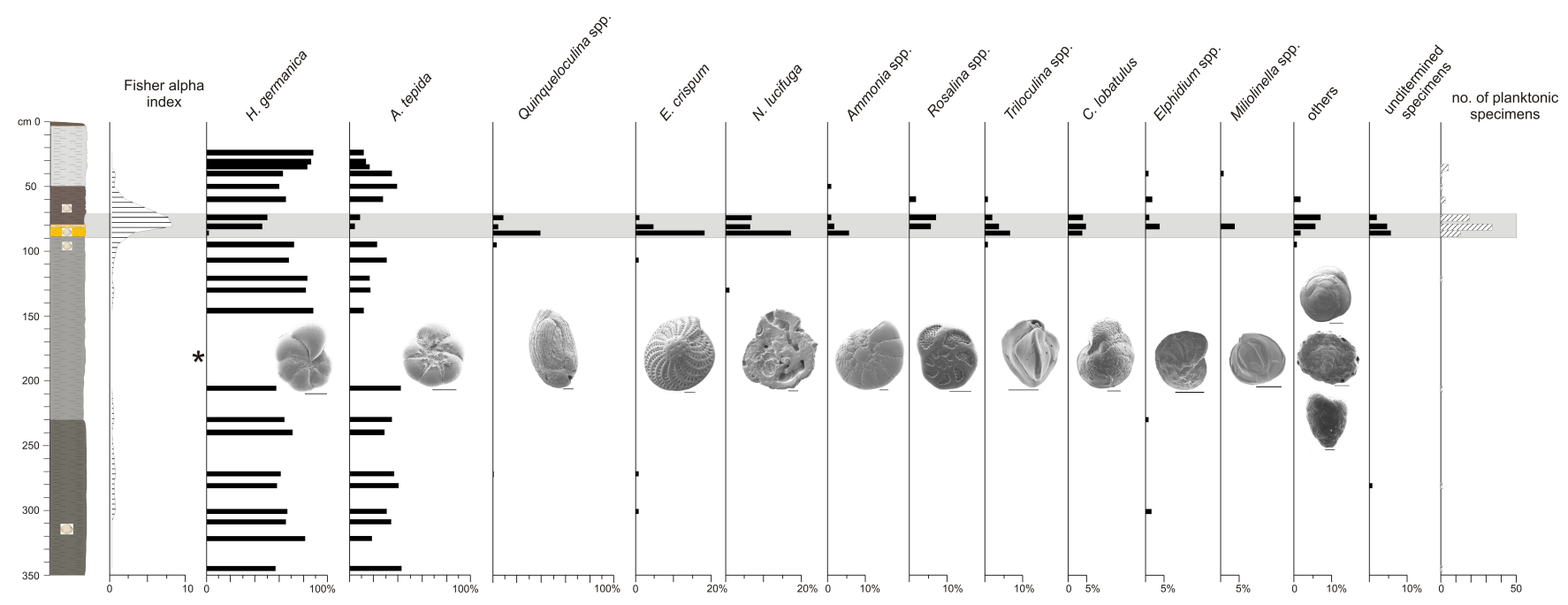

Fig. 6. Benthic foraminifera abundance data (expressed as relative frequency of the total assemblage), the Fisher alpha index plot and the total number of planktonic foraminifera per sample from the western part of Pantano Morghella (core S12, see Fig. 2 for location). The star marks a sample by which the foraminifera concentration was not sufficient to reach 100 specimens. Scanning electron micrographs (bar length $=100 \mu \mathrm{m}$ ) of selected species (from the left Haynesina germanica (Ehrenberg), Ammonia tepida (Cushman), Quinqueloculina poeyana d'Orbigny, Elphidium crispum (Linnaeus), Nubecularia lucifuga Defrance, Ammonia parkinsoniana (d'Orbigny), Rosalina bradyi (Cushman), Triloculina tricarinata d'Orbigny, Cibicides lobatulus (Walker and Jacob), Elphidium sp., Miliolinella semicostata (Wiesner) Asterigerinata mamilla (Williamson), Sorites orbicularis (Forskål), Textularia sp.). The gray horizontal bar indicates those samples influenced by the deposition of the MOR-T02 layer. For the legend of the core see Fig. 4.

that this latter group increases up to $83 \%$ of the total in the MOR-T01 interval.

Moreover, the allochthonous assemblage shows an important percentage (up to $38 \%$ ) also in the uppermost part of the stratigraphical sequence (Fig. 7a) testifying a possible dispersion of the peculiar coarse deposit into few decimetres above or an anthropic input related to the recent history of the site as salt pan (marine water pumped in the eastern sector).

As well as for MOR-T02, the sandy samples from MOR$\mathrm{T} 01$ are rich in smoothed bioclastic clasts and remains of sea urchins, corals, sponge spicules, bryozoa and molluscs suggesting a similar, if not identical, mechanism of transport/deposition (Fig. 7c).

Furthermore, a qualitative comparison between the sand collected on the foreshore (Fig. 2) and the sandy samples from the cores illustrated above was carried out (Fig. 7c). In fact, the sand beach contains many smoothed bioclastic clasts identifiable as shell fragments, remains of molluscs, sea urchins, corals, as well as benthic foraminifera from the near-shore (e.g., the genus Ammonia, Cibicides, Quinqueloculina, Peneroplis, and Rosalina) and rare, badly preserved planktonic foraminifera (Fig. 7c). Thus, the sand beach content appears to be very similar to the dominant content found in MOR-T01 and MOR-T02 sandy intervals.

\subsection{Chronological constraints}

In order to estimate the sandy layers deposition age, to clarify if the two levels are coeval, and to obtain the age of the whole stratigraphic sequence, the results coming from two different dating methods, i.e., radiocarbon and OSL, were used.

As for the radiocarbon measurements, chronological constraints are based on 8 samples (Table 2). In detail, we collected 3 samples (S12-69, S12-85 and S12-97) just above, within and below the MOR-T02 sandy layer, for which we also dated 1 sample collected below it from core S39 (S39142); the only radiocarbon constraint available for the sandy layer MOR-T01 comes from the core S51 and was collected just below it (S51-26). Moreover, 3 samples (S12-312, S39415 and S51-284) were dated to derive average sedimentation rates.

Radiocarbon dating results constrain the deposition of the MOR-T01 layer (Fig. 7) to an age that should be younger than $1640 \mathrm{AD}$ (or $1710 \mathrm{AD}$, if we take into account the $\Delta R$ ). Radiocarbon dating performed on the three closely spaced samples from core S12 furnishes age intervals close in time, supporting the hypothesis of a sudden deposition for the MOR-T02 layer, rather than a gradual transition to a higher energy environment. These results confine the age of the MOR-T02 sandy layer in the interval 270-600 AD (or $370-740 \mathrm{AD}$ if we take into account the $\Delta R$ ). Noteworthy, the latter result is coherent with the age obtained from the sample collected below the MOR-T02 deposit in core 


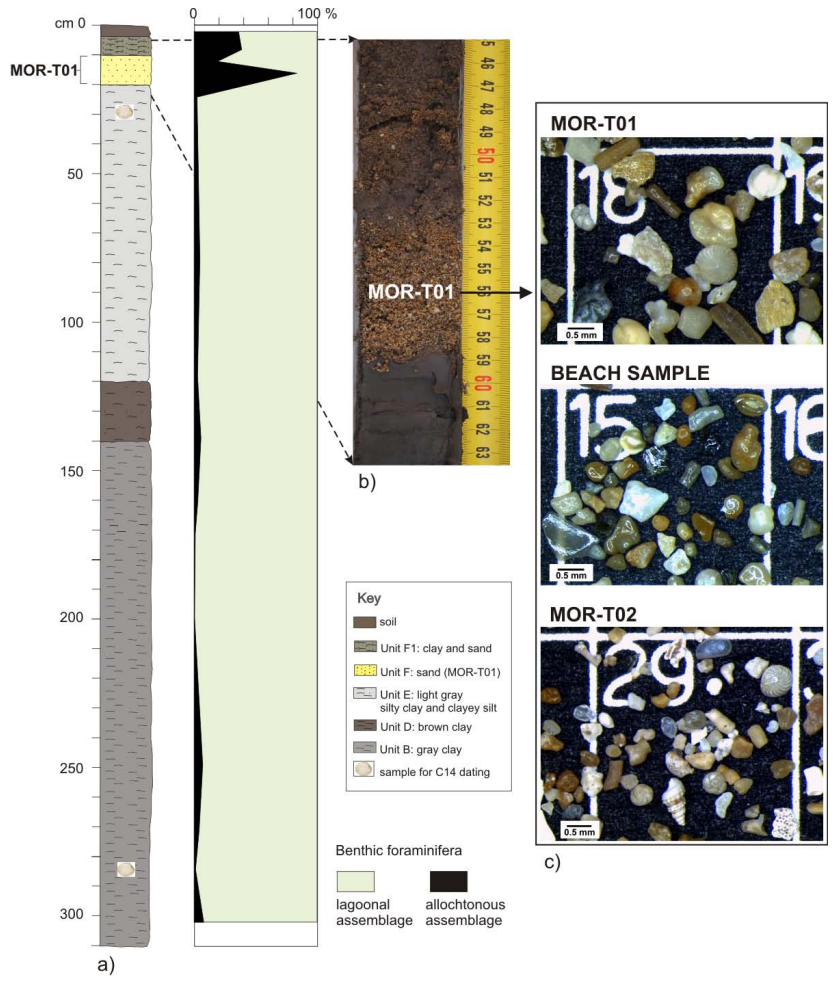

Fig. 7. (a) S51 core log coupled with a down core distribution of the benthic foraminifera assemblage; (b) core picture from $24 \mathrm{~cm}$ to $6 \mathrm{~cm}$ of depth showing the MOR-T01 sandy interval; (c) three examples of washed residues are illustrated: MOR-T01 from the S51-3 sample, MOR-T02 from S12-8 sample and the sand beach sample was collected on the foreshore.

S39, suggesting that it should be younger than $140 \mathrm{AD}$ (or $240 \mathrm{AD}$, if we take into account the $\Delta R$ ).

Finally, using also the radiocarbon dating of the deepest 3 samples S12-312, S39-415 and S51-284 (Table 2) we can derive an average sedimentation rate of $0.85 \pm 0.15 \mathrm{~mm} \mathrm{yr}^{-1}$.

OSL technique was carried out in the samples obtained from the MOR-T01 sand found in the core S39 and in MOR-T02 sandy layer detected in the cores S100-101-102 (Fig. 2a).

The ED and the DR values considered for the age calculation are reported for all samples in Table 3. The same table shows the fraction used with related granulometry, the measurement protocol, the OSL ages and corresponding dates in AD.

OSL dating on S39 core constrains the age of the MORT02 sandy layer in the interval $368 \pm 132 \mathrm{AD}$; the results of MOR-T01 dating performed on three cores (S100, S101 and S102) are coherent and limit its deposition in the last century (Table 3).

The use of two chronological approaches (radiocarbon and luminescence) resulted to be very positive. In fact, on one side the different methodologies pointed to comparable results, thus, corroborating and implicitly validating each other, on the other hand, it gave us the unique chance of narrowing significantly the most probable time window of deposition of some specific layers.

\section{Discussion}

The stratigraphic reconstruction performed on 40 cores at Pantano Morghella shows a sequence made of fine grained sediments that can be divided into four main units: from the maximum reached depth $(5.80 \mathrm{~m})$ an alternation of graybrownish silty clay and clayey silt (UNIT A) is followed by gray clay (UNIT B), by brown clay (UNIT D) above which a light gray silty clay and clayey silt (UNIT E) lies; on the top a brownish soil was observed (Figs. 3, 4 and 5). The sequence contains numerous shell fragments, small whole shells and vegetal remains. The paleontological analysis revealed an oligothipic fauna assemblage of lagoonal setting (Figs. 6 and 7), confirming Pantano Morghella as a low-energy depositional environment. Within this lagoonal setting, the coarse yellow sandy layers (MOR-T02 and MOR-T01 in Figs. 3, 4, 5, 6 and 7) represent the only two anomalous high-energy levels with respect to the local sedimentary environment. Moreover, we noted that in many cores, these sandy layers are followed by a thin clayey sheet. The results of paleontological analysis show that both MOR-T02 and MOR-T01 deposits are characterised by abundant shell debris made of molluscs, sea urchins, corals, sponge spicules and bryozoa; moreover an overall increased diversity in the foraminiferal assemblage is evident since numerous additional open marine benthic species appear (Figs. 6 and 7). Both the grain size and the fauna content found in MOR-T02 and MORT01 sandy intervals appear to be similar to those of the sand collected from the foreshore (Fig. 7c), pointing to this area as the most probable source.

Even if MOR-T02 and MOR-T01 layers share similar characteristics, their spatial distribution within Pantano Morghella and stratigraphical position in the studied sequence are different suggesting two distinct episodes of emplacement. The MOR-T02 layer was detected in most of the numerous cores dug in the central and western area of the pond; it thins and becomes finer grained, better sorted and skewed increasing the distance from the shore (Fig. 8). Radiocarbon dating performed on the three samples of S12 core, collected above, within and below the coarse layer (Table 2), give ages close in time, supporting the hypothesis of a sudden inundation rather than a gradual transition to a higher energy environment. Differently, the MOR-T01 deposit was found in the cores dug in the eastern part of Pantano Morghella and it was observed from $300 \mathrm{~m}$ up to $380 \mathrm{~m}$ of distance from the coastline.

Summarizing, sedimentological features of MOR-T02 and MOR-T01 (grain size, fining-upward, presence of a thin clayey sheet on top and sharp/erosional basal contact) jointly 


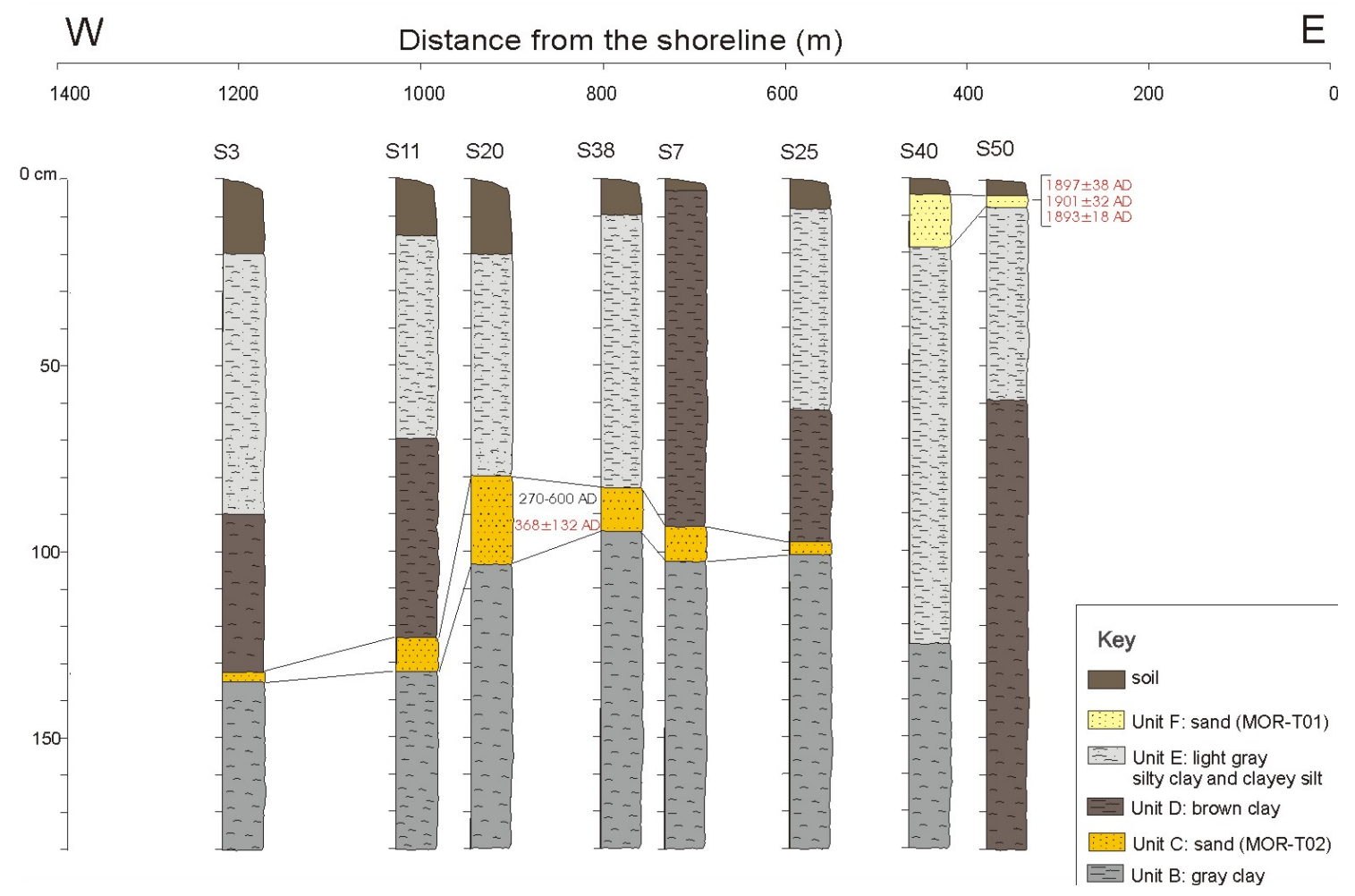

Fig. 8. Logs representing Pantano Morghella stratigraphy from $0 \mathrm{~cm}$ to $1.80 \mathrm{~m}$ of depth. The black and red dates indicate the results of radiocarbon and OSL dating, respectively.

with observations on macro-micropaleontological content provide strong evidence for a marked and sudden change in depositional mechanism suggesting the occurrence of exceptionally high-energy depositional events due to marine inundations.

In order to discriminate the origin of MOR-T02 and MORT01 between tsunami and storm deposits, we defined the storm deposition limit in the study area. Besides, we compared the age of the reconstructed stratigraphic sequence with the frequency of the strongest storms which occurred in the Ionian Sea knowing that major tsunamis are less frequent events than coastal storms (Morton et al., 2007).

Considering the MOR-T02 and MOR-T01 distribution within the pond (from a minimum investigated distance from the coastline of $300 \mathrm{~m}$ up to a maximum of $380 \mathrm{~m}$ for MORT01 and $1200 \mathrm{~m}$ for MOR-T02), these levels are beyond the maximum storm flooding evaluated at the study site (about $60 \mathrm{~m}$ from the shore) (Table 1).

From a meteorological observations dataset (European Center for Medium-Range Weather Forecasts, ERA-40 Data Archive: a re-analysis of global atmosphere and surface conditions from 1957 through 2002 - available at: http://www.ecmwf.int/products/data/archive/descriptions/e4), nine strong cyclonic areas developed during the past $45 \mathrm{yr}$ in the study region (see also De Martini et al., 2010; Smedile et al., 2011). By comparing the frequency of these storms in the Ionian Sea with the age of more than $6000 \mathrm{yr}$ for the investigated stratigraphic sequence derived from the average sedimentation rate, we would expect more than 1000 exceptional storms during the time-line recorded in Pantano Morghella cores. Hence, we would have to find an amount of layers linked to high energy depositional storm events substantially more numerous than those observed at Pantano Morghella (MOR-T02 and MOR-T01). Therefore, since the sedimentological and paleontological characteristics of the studied layers, their distance from the shoreline, their ages and frequency in the stratigraphic sequence, we interpret the anomalous sandy layers (MOR-T02 and MOR-T01) as tsunami deposits. Though nowhere encountered in vertical stratigraphic sequence in the same core, the two units (MORT02 and MOR-T01) are clearly superposed stratigraphically and can be also distinguished by radiocarbon and OSL ages.

Concerning MOR-T02 deposit, radiocarbon dating constrain the marine inundation age to the interval 270-600 AD. This relatively large time-windows is narrowed by the OSL result that matches with radiocarbon ones and restricts the occurrence of tsunami to $368 \pm 132 \mathrm{AD}$. Comparing this age with the historical tsunami catalogue, we suggest that MORT02 could represent the geological record of the $365 \mathrm{AD}$ Crete tsunami.

In spite of the $365 \mathrm{AD}$ Crete tsunami inundated several locations in coastal areas from Egypt to Croatia (Fig. 1b) 


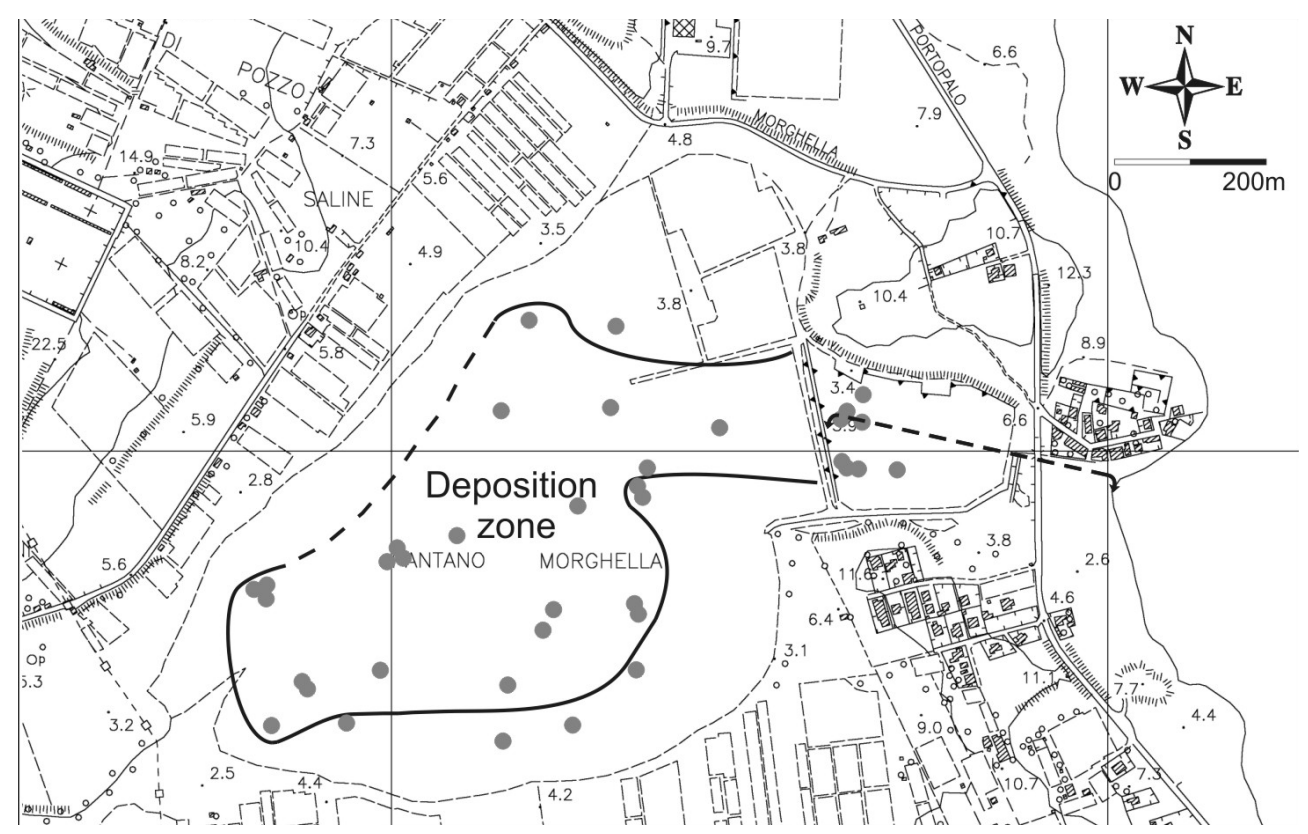

Fig. 9. Topographic map of Pantano Morghella site; the gray dots indicate core location. The black line delimits the area where the sandy layer MOR-T02, probably related to the $365 \mathrm{AD}$ tsunami, has been found at about $1 \mathrm{~m}$ of depth. The dashed line with arrows shows the probable erosion/by pass (no sedimentation) area.

(Guidoboni et al., 1994; Stiros, 2001), its deposit has never been found with certain sedimentary evidence (see Scheffers and Scheffers, 2007 for a review) with the exception of recent findings at the Lake Voulkaria (NW Greece) (Vött et al., 2009) and in eastern Sicily. In this latter area, geological evidence for the $365 \mathrm{AD}$ Crete tsunami was found at Augusta Bay (55 km to the North) both in land (De Martini et al., 2010) and off shore (Smedile et al., 2011) and probably at the Gurna site (120 km to the North) in the eastern flank of Mt. Etna (Barbano et al., 2009) (Fig. 1a). These findings, jointly with historical information, describing that "the sea flowed over the shore, causing suffering to countless people in Sicily (Jerome, 1956)" and tsunami source modelling computing waves up to about $2 \mathrm{~m}$ at Siracusa (Lorito et al., 2008) seem to support the hypothesis that MOR-T02 deposit could be associated with the $365 \mathrm{AD}$ Crete tsunami.

Radiocarbon dating constrains the MOR-T01 age after 1640 AD. Comparing this tsunami deposit age with the historical tsunami catalogue, we can hypothesize that it represents the geological record of the 1693 or 1908 tsunami inundation. Although historical accounts do not report descriptions of tsunami inundation at Pantano Morghella, during both the 11 January 1693 and 28 December 1908 events, several villages located near the pond were more or less inundated (Fig. 1a) and tsunami deposits related to both 1693 and 1908 events were found in the Augusta Bay (De Martini et al., 2010; Smedile et al., 2011) and near Siracusa (Scicchitano et al., 2010).
OSL dating performed on S100, S101 and S102 cores allowed narrowing MORT-01 deposition age and to discriminate between the 1693 and 1908 tsunami. The results (Table 3) suggest that MOR-T01 sandy layer was deposited by the 1908 tsunami.

The numerous cores dug in Pantano Morghella allowed marking out the probable inundation limit of the 1908 event (about $380 \mathrm{~m}$ ) and the minimum inundation boundary of the $365 \mathrm{AD}$ Crete tsunami (up to $1.2 \mathrm{~km}$ from the coastline) (Fig. 9); for this latter event, we can also trace a tsunami deposition area of about $0.250 \mathrm{~km}^{2}$ and a zone of erosion/bypass seaward of the tsunami wave (Gelfenbaum and Jaffe, 2003) of about $400 \mathrm{~m}$, as testified by the lack of MOR-T02 in the cores dug in the old salt-pans (Figs. 8 and 9). The fact that the erosion area was also important is testified by the clayey rip-up clasts found in several logs within the sandy layer MOR-T02 (Fig. 4).

From historical data, we would aspect to find more tsunami deposits in our long stratigraphic sequence. Finding geological evidence of only two events could be explained considering that the site is probably not well exposed to the tsunamigenic near-sources, i.e., the Malta escarpment fault system (Fig. 1a) that is considered the source of the strongest historical tsunamigenic earthquakes that affected south-eastern Sicily, such as the 1169 and 1693 events. Indeed the coastal dunes closing the pond in the northeastern area (Fig. 2) could have attenuated the action of extreme waves approaching from the NE that could represent plausible direction of tsunami waves since the location of 
tsumamigenic bordering-coast sources (Fig. 1a). Whereas Pantano Morghella seems more exposed to the effects of waves coming from ESE and this direction is compatible with the tsunamis originated from the far-away Greek sources. Therefore, the absence of tsunami near-source geologic records could be explained by the geomorphological setting of Pantano Morghella. In our opinion, the presence of 1908 tsunami deposit could be related to the salt pan works beginning in the first years of the 20th century (Marletta, 2002). Indeed the historical information about 1908 tsunami report low values of both run up (1-3 m) and inundation (10-15 m) in localities close to Pantano Morghella; so the estimated inundation of approx. $380 \mathrm{~m}$ could be related to the construction of the channel, required to carry the water into the pond, representing the only path through which the tsunami could move inland.

The concentration of the two levels in the first metre of the stratigraphic sequence and the absence of further tsunami records up to about $5.80 \mathrm{~m}$ of depth are probably due to an initial isolation of the pond from the sea due to the growing of the dunes, potentially broken by the $365 \mathrm{AD}$ event. Indeed, geological evidence of this tsunami at this site and in other sites along the Ionian coast should indicate that it strongly affected southern Sicily, also modifying important morphologic coastal features.

\section{Conclusions}

Shallow drilling in the Pantano Morghella area provided geological evidence for two tsunami inundations occurred along the south-eastern Ionian coast of Sicily. Pantano Morghella is characterised by a sedimentation indicating low-energy depositional environment and the two anomalous yellow sandy layers found at different depth indicate the occurrence of high-energy marine inundations. We investigated sedimentological and paleontological characteristics of the anomalous deposits as well as their spatial distribution observing the following properties as typical of the coastal tsunamiites: different facies with respect to the local stratigraphic sequence; paleontological content showing macrofaunal and foraminifera assemblages from shallow to open marine environment; erosive bases, rip-up clasts and broken elements testifying violent deposition mechanisms; deposit thickness is relatively constant throughout most of the depositional zone with thinning at the distal end; large inland-extending of the sand sheets, infrequency in the sedimentary record, age indicating a fast deposition. Comparing the results of radiocarbon and OSL dating with the historical tsunami catalogue, we suggest that the two anomalous sandy deposits represent the records of the 365 AD Crete tsunami and possibly the 1908 Messina Straits tsunami.

The different extension of inundation associated with the two historical events (up to $1.2 \mathrm{~km}$ for the $365 \mathrm{AD}$ tsunami and about $380 \mathrm{~m}$ for the 1908 event) can be due to the probable different geometry of the two tsunami sources (normal fault vs. thrust), to different tsunami magnitude considering that the 365 earthquake $\left(M_{\mathrm{w}}=8.3-8.5\right.$ according to Shaw et al., 2008) was certainly stronger than the 1908 one ( $M_{\mathrm{w}}=7.1$, Pino et al., 2000) and to the different setting of the pond prior and after the salt-works done at the beginning of the 20th century.

If we compare these results with the latest research dealing with paleo-tsunamis in the region, we may note that geological evidence of the 365 AD Crete tsunami observed at Pantano Morghella is in agreement and corroborate the previous findings at Augusta Bay both in land (De Martini et al., 2010) and off shore (Smedile et al., 2011), probably at the Gurna site, in the eastern flank of Mt. Etna (Barbano et al., 2009) and at the Ognina site to the south of Siracusa (Schicchitano et al., 2010). Regarding the 1908 tsunami, differently from other investigated sites along eastern Sicily where the intense twentieth-century urbanization of the costal areas and superficial erosional processes may have removed its tsunami signatures (Pantosti et al., 2008; Barbano et al. 2009; De Martini et al., 2010), Pantano Morghella preserved the 1908 deposit thanks to its trap-like morphological configuration and its ponding behaviour that prevented its agricultural usage as well as any urbanisation.

The identification and characterisation of geological evidence of past tsunamis (useful to obtain tsunami recurrence time, maximum inundation distance, elapsed time since the last tsunami event, etc.) may have a significant relevance for Civil Protection applications, reason being these data are easily usable in the field of tsunami scenario and modelling. Our tsunami deposit research seems to prove on one hand that the geological records can provide more reliable data about coastal inundation than the ones coming from the historical reports as also verified by De Martini et al. (2010) at Augusta Bay, where the tsunami inundation limit derived by geological data is three times farther than the distance described by historical accounts; on the other hand, the tsunami deposits of some known historical events were not preserved because of natural or anthropic factors (e.g., bioturbations, superficial erosional processes, human activity along the coastline). Finally, our findings also showed that inundations from far tsunamigenic sources can be much wider. So, although their infrequency, these tsunamis can be more dangerous than frequent ones because people living close to sea are not conscious of the risks. The next large tsunami might return after several generations and the only way to be adequately prepared is to ensure that local communities sustain awareness of tsunami hazard.

Acknowledgements. This work was funded by Italian Civil Protection Department in the frame of the 2007-2009 agreement with Istituto Nazionale di Geofisica e Vulcanologia-INGV (Seismological Project S1). We are indebted to Dott. L. Bellucci, from ISMARCNR-Geologia Marina, Bologna, for the help provided for the Xray analyses. Special thanks to N. Guardone, M. Mazzeo, A. Rapicavoli and V. Sparti for their technical assistance in carrying out the 
OSL section of this work and R. Leonardi for his assistance in the sedimentological laboratory. A. Cavallo is kindly acknowledged for the assistance of SEM pictures performed at INGV-Roma. We also thank the students G. Fazio, F. La Rosa and M. Raniolo in helping us with core recovering and logging, and Mr. Angelo for his hospitality at the Pantano Morghella site.

We wish to thank R. Paris and an anonymous reviewer whose suggestions contributed to improve the original manuscript.

Edited by: E. Gràcia

Reviewed by: R. Paris and another anonymous referee

\section{References}

Adamiec, G. and Aitken, M. J.: Dose-rate conversion factors: new data, Ancient TL 16, 37-50, 1998.

Aitken, M. J.: Thermoluminescence Dating, Academic Press, London, 359 pp., 1985.

Aitken, M. J.: An Introduction to Optical Dating. The Dating of Quaternary Sediments by the Use of Photon-stimulated Luminescence, Oxford Science Publications, 267 pp., 1998.

Antonioli, F., Ferranti, L., Fontana, A., Amorosi, A., Bondesan, A., Braitenberg, C., Dutton, A., Fontolan, G., Furlani, S., Lambeck, K., Mastronuzzi, G., Monaco, C., Spada, G., and Stocchi, P.: Holocene relative sea-level changes and vertical movements along the Italian and Istrian coastlines, Quatern. Int., 206, 102133, 2009.

Atwater, B. F. and Moore, A. L.: A tsunami about 1000 years ago in Puget Sound, Washington, Science, 258, 1614-1617, 1992.

Atwater, B. F., Musumi-Rokkaku, S., Satake, K., Tsuji, Y., Ueda, K., and Yamaguchi, D. K.: The orphan tsunami of 1700; Japanese clues to a parent earthquake in North America, Report P, 1707, 133 pp., 2005.

Banerjee, D., Murray, A. S., and Foster, I. D. L.: Scilly Isles, UK: optical dating of a possible tsunami deposit from the 1755 Lisbon earthquake, Quaternary Sci. Rev., 20, 715-718, 2001.

Baratta, M.: La catastrofe sismica calabro-messinese (28 Dicembre 1908), Relazione alla Società Geografica Italiana, Roma, 426 pp., 1910.

Barbano, M. S., De Martini, P. M., Pantosti, D., Smedile, A., Del Carlo, P., Gerardi, F., Guarnieri, P., and Pirrotta, C.: In search of tsunami deposits along the eastern coast of Sicily (Italy): state of the art, in: Recent Progress on Earthquake Geology, edited by: Guarnieri, P. P., Nova Science Publishers, 109-146, 2009.

Barbano, M. S., Pirrotta, C., and Gerardi, F.: Large boulders along the south-eastern Ionian coast of Sicily: storm or tsunami deposits?, Mar. Geol., 275, 140-154, 2010.

Bianca, M., Catalano, S., De Guidi, G., Gueli, A. M., Monaco, C., Ristuccia, G. M., Stella, G., Tortorici, G., Tortorici, L., and Troja, S. O.: Luminescence chronology of Pleistocene marine terraces of Capo Vaticano peninsula (Calabria, Southern Italy), Quatern. Int., 232, 114-121, 2011.

Boschi, E., Guidoboni, E., Ferrari, G., Gasperini, P., Mariotti, D., and Valensise, G.: Catalogue of strong earthquakes in Italy from 461 B.C. to 1997, Ann. Geof., 43 (4), 843-868 and CD-ROM, 2000.

Bøtter-Jensen, L, Mckeever, S. W. S., and Wintle, A. G.: Optical stimulation luminescence dosimetry, Elsevier Sciences B.V., 302 pp., 2003.

Bourgeois, J.: Geologic effects and records of tsunamis, in: The Sea: Volume 15, Tsunamis, edited by: Bernard, E. N. and Robinson, A. R., Cambridge, Massachusetts, Harvard University Press, 55-91, 2009.

Bourgeois, J., Pinegina, T. K., Ponomareva, V., and Zaretskaia, N.: Holocene tsunamis in the southwestern Bering Sea, Russian Far East, and their tectonic implications, Geol. Soc. Am. Bull., 118, 449-463, 2006.

Cimerman, F. and Langer, M. R.: Mediterranean foraminifera, Academia Scientiarum et Artium Slovenica Classis IV 30, Ljubljana, 118 pp., 1991.

Chagué-Goff, C., Schneider, J.-L., Goff, J., Dominey-Howes, D., and Strotz, L.: Expanding the proxy toolkit to help identify past events: Lessons from the 2004 Indian Ocean Tsunami and the 2009 South Pacific Tsunami, Earth-Sci. Rev., 107, 107-122, 2011.

Cunha, P. P., Buylaert, J. P., Murray, A. S., Andrade, C., Freitas, M. C., Fatela, F., Munhà, J. M., Martins, A. A., and Sugisaki, S.: Optical dating of clastic deposits generated by an extreme marine coastal flood: The 1755 tsunami deposits in the Alagarve (Portugal), Quat. Geochron., 5, 329-335, 2010.

De Martini, P. M., Burrato, P., Pantosti, D., Maramai, A., Graziani, L., and Abramson, H.: Identification of liquefaction features and tsunami deposits in the Gargano area (Italy): a geologic contribution to the hazard assessment, Ann. Geoph., 46, 883-902, 2003.

De Martini, P. M., Barbano, M. S., Smedile, A., Gerardi, F., Pantosti, D., Del Carlo, P., and Pirrotta, C.: A unique 4000 yrs long geological record of multiple tsunami inundations in the Augusta Bay (eastern Sicily, Italy), Mar. Geol., 276, 42-57, 2010.

Dominey-Howes, D. T. M.: A re-analysis of the Late Bronze Age eruption and tsunami of Santorini, Greece, and the implications for the volcano-tsunami hazard, J. Volcanol. Geoth. Res., 130, 107-132, 2004.

Dominey-Howes, D. T. M.: Geological and historical records of tsunami in Australia, Mar. Geol., 239, 99-123, 2007.

Ferranti, L., Antonioli, F., Mauz, B., Amorosi, A., Dai Pra, G., Mastronuzzi, G., Monaco, C., Orru', P., Pappalardo, M., Radtke, U., Renda, P., Romano, P., Sansò, P., and Verrubbi, V.: Markers of the last interglacial sea level high stand along the coast of Italy: tectonic implications, Quatern. Int., 145-146, 30-54, 2006.

Gelfenbaum, G. and Jaffe, B.: Erosion and sedimentation from the 17 July 1998 Papua New Guinea tsunami, Pure Appl. Geophys., 160, 1969-1999, 2003.

Gerardi, F., Barbano, M. S., De Martini, P. M. and Pantosti, D.: Discrimination of tsunami sources (earthquake vs. landslide) on the basis of historical data in eastern Sicily and southern Calabria, Bull. Seism. Soc. Am., 98, 2795-2805, 2008.

Gianfreda, F., Mastronuzzi, G., and Sansò, P.: Impact of historical tsunamis on a sandy coastal barrier: an example from the northern Gargano coast, southern Italy, Nat. Hazards Earth Syst. Sci., 1, 213-219, doi:10.5194/nhess-1-213-2001, 2001.

Goff, J., McFadgen, B. G., and Chagué-Goff, C.: Sedimentary differences between the 2002 Easter storm and the 15th Century Okoropunga tsunami, southeastern North Island, New Zealand, Mar. Geol., 204, 235-250, 2004.

Goff, J., Nichol, S., Chagué-Goff, C., Horrocks, M., McFadgen, B., and Cisternas, M.: Predecessor to New Zealand's largest historic trans-South Pacific tsunami of 1868 AD, Mar. Geol., 275, 155- 
165, 2010a.

Goff, J. R., Pearce, S., Nichol, S. L., Chagué-Goff, C., Horrocks, M., and Strotz, L.: Multiproxy records of regionally-sourced tsunamis, New Zealand, Geomorphology, 118, 369-382, 2010b.

Guidoboni, E., Comastri, A., and Traina, G.: Catalogue of ancient earthquakes in the Mediterranean area up to the 10th century, Istituto Nazionale di Geofisica and Storia Geofisica Ambiente, Editrice compositori srl, Bologna, Italy, 504 pp., 1994.

Hammer, Ø., Harper, D. A. T., and Ryan, P. D.: PAST: Paleontological Statistics Software Package for Education and Data Analysis, Palaeontol. Electron., 4, 9 pp., 2001.

Huntley, D. J., Godfrey-Smith, D. I., and Thewalt, M. L. W.: Optical dating of sediments, Nature, 313, 105-107, 1985.

Huntley, D. and Clague, J. J.: Optical dating of tsunami-land sands, Quaternary Res., 46, 127-140, 1996.

Jerome: 380 Chonicon Eusebii, Eusebius Chonicon, edited by: Helm, R., GSC 47, Berlin, 1956.

Kim, J. C., Roberts, H. M., Duller, G. A. T., Lee, Y. I., and Yi, S. B.: Assessment of diagnostic tests for evaluating the reliability of SAR De values from polymineral and quartz fine grains, Radiat. Meas., 44, 149-157, 2009.

Kiyak, N. G. and Canel, T.: Equivalent dose in quartz from young samples using the SAR protocol and the effect of preheat temperature, Radiat. Meas., 41, 917-922, 2006.

Kortekaas, S. and Dawson, A. G.: Distinguishing tsunami and storm deposits: an example from Martinhal, SW Portugal, Sediment. Geol., 200, 208-221, 2007.

Istituto Idrografico della Marina: Carta Nautica da Capo Passero a Capo S. Croce, scala 1:100.000, 1999.

Lentini, F., Carbone, S., Cugno, G., Grasso, M., Scamarda, G., Sciuto, F., Montanari, L., Romeo, M., and Ferrara, V.: Geological map of the north-eastern Hyblean sector, S.EL.CA. Società Elaborazioni Cartografiche, Map scale 1:50.000, Firenze (in Italian), 1986.

Lentini, F., Carbone, S., and Catalano, S.: Main structural domains of the central Mediterranean region and their Neogene tectonic evolution, Boll. Geofis. Teor. Appl., 36, 103-125, 1994.

Lentini, F., Carbone, S., and Guarnieri, P.: Collisional and postcollisional tectonics of the Apenninic-Maghrebian Orogen (Southern Italy), in: Postcollisional tectonics and magmatism in the Mediterranean region and Asia, edited by: Dilek, Y. and Pavlides, S., Geological Society of America Special Papers, 409, 57-81, 2006.

Lorito, S., Tiberti, M. M., Basili, R., Piatanesi, A., and Valensise, G.: Earthquake-generated tsunamis in the Mediterranean Sea: Scenarios of potential threats to Southern Italy, J. Geophys. Res., 113, B01301, doi:10.1029/2007JB004943, 2008.

Mamo, B., Strotz, L., and Dominey-Howes, D.: Tsunami sediments and their foraminiferal assemblages, Earth Sci. Rev., 96, 263278, 2009 .

Marletta, G: Tra scupazzi, cciappiri, sparaci e satareddi di Marzameni, Marzameni, Agorà X, a. III, Luglio - Settembre 2002, 72 75, available at: www.editorialeagora.it, 2002.

Mastronuzzi, G. and Sansò, P.: Boulders transport by catastrophic waves along the Ionian coast of Apulia (southern Italy), Mar. Geol., 170, 93-103, 2000.

Mastronuzzi, G., Pignatelli, C., Sansò, P., and Selleri, G.: Boulder accumulations produced by the 20th of February, 1743 tsunami along the coast of southeastern Salento (Apulia region, Italy),
Mar. Geol., 242, 191-205, 2007.

Mejdahl, V.: Thermoluminescence dating: beta-dose attenuation in quartz grains, Archaeometry, 21, 61-72, 1979.

Minoura, K., Nakaya, S., and Uchida, M.: Tsunami deposits in a lacustrine sequence of the Sanriku coast, northeast Japan, Sediment. Geol., 89, 25-31, 1994.

Monaco, C., Catalano, S., Cocina, O., De Guidi, G., Ferlito, C., Gresta, S., Musumeci, C., and Tortorici, L.: Tectonic control on the eruptive dynamics at Mt. Etna Volcano (Sicily) during the 2001-2003 eruptions, J. Volcanol. Geoth. Res., 144, 211-233, 2005.

Morton, R. A., Gelfenbaum, G., and Jaffe, B. E.: Physical criteria for distinguishing sandy tsunami and storm deposits using modern examples, Sediment. Geol., 200, 184-207, 2007.

Murray, A. S. and Wintle, A. G.: Luminescence dating of quartz using an improved single-aliquot regenerative-dose protocol, Radiat. Meas., 32, 57-73, 2000.

Murray, A. S. and Wintle, A. G.: The single aliquot regenerative dose protocol: potential for improvements in reliability, Radiat. Meas., 37, 377-381, 2003.

Murray, J. W.: Ecology and applications of Benthic Foraminifera, Cambridge University Press, Cambridge, 426 pp., 2006.

Nanayama, F., Shigeno, K., Satake, K., Shimokawa, K., Koitabashi, S., Miyasaka, S. and Ishii, M.: Sedimentary differences between the 1993 Hokkaido-Nansei-Oki tsunami and the 1959 Miyakojima typhoon at Taisei, southwestern Hokkaido, northern Japan, Sediment. Geol., 135, 255-264, 2000.

Pantosti, D., Barbano, M. S., De Martini, P. M., and Smedile, A.: Geological Evidence of Paleotsunamis at Torre degli Inglesi (NE Sicily), Geophys. Res. Lett., 35, L05311, doi:10.1029/2007GL032935, 2008.

Peres, J. M. and Picard, J.: Nouveau manuel de Bionomie bentique de la mer Mediterranée, Rec. Trav. Station Marine d'Endoume, 31, 1-137, 1964.

Peters, R. and Jaffe, B. E.: Identification of tsunami deposits in the geologic record; developing criteria using recent tsunami deposits: U.S. Geological Survey Open-File Report 2010-1239, 39 pp., available at: http://pubs.usgs.gov/of/2010/1239/, 2010.

Pignatelli, C., Sansò, P., and Mastronuzzi, G.: Evaluation of tsunami flooding using geomorphological evidence, Mar. Geol., 260, 6-18, 2009.

Pino, N. A., Giardini, D., and Boschi, E.: The December 28, 1908, Messina Straits, southern Italy, earthquake: Waveform modelling of regional seismograms, J. Geophys. Res., 105, 25473-25492, 2000.

Platania, G.: Il Maremoto dello Stretto di Messina del 28 dicembre 1908, Boll. Soc. Sismol. It., 13, 369-458, 1909.

Prescott, J. R. and Hutton, J. T.: Cosmic ray contributions to doserates for luminescence and ESR dating: large depths and long terms time variations, Radiat. Meas., 23, 497-500, 1994.

Reimer, P. J., Baillie, M. G. L., Bard, E., Bayliss, A., Beck, J. W., Blackwell, P. G., Bronk Ramsey, C., Buck, C. E., Burr, G. S., Edwards, R. L., Friedrich, M., Grootes, P. M., Guilderson, T. P., Hajdas, I., Heaton, T. J., Hogg, A. G., Hughen, K. A., Kaiser, K. F., Kromer, B., McCormac, F. G., Manning, S. W., Reimer, R. W., Richards, D. A., Southon, J. R., Talamo, S., Turney, C. S. M., van der Plicht, J., and Weyhenmeyer, C. E.: IntCal09 and Marine09 radiocarbon age calibration curves, $0-50,000$ years cal BP, Radiocarbon, 51, 1111-1150, 2009. 
Roberts, H. M.: Assessing the effectiveness of the double-SAR protocol in isolating a luminescence signal dominated by quartz, Radiat. Meas., 42, 1627-1636, 2007.

Roberts, H. M. and Wintle, A. G.: Equivalent dose determinations for polymineralic fine-grains using the SAR protocol: application to a Holocene sequence of the Chinese Loess Plateau, Quaternary Sci. Rev., 20, 859-863, 2001.

Ruiz, F., Rodríguez-Ramírez, A., Cáceres, L. M., Rodríguez Vidal, J., Carretero, M. I., Abad, M., Olías, M., and Pozo, M.: Evidence of high-energy events in the geological record: mid-Holocene evolution of the southwestern Doñana National Park (SW Spain), Palaeogeog. Palaeocl. Palaeoec., 229, 212-229, 2005.

Sarpkaya, T. and Isaacson, M.: Mechanics of Wave Forces on Offshore Structures, Van Nostrand Reinhold Company Inc., 650 pp., 1981.

Scheffers, A. and Scheffers, S. R.: Tsunami deposits on the coastline of West Crete (Greece), Earth Planet. Sci. Lett., 259, 613624, 2007.

Scheffers, A., Kelletat, D., Vött, A., Matthias May, S., and Scheffers, S.: Late Holocene tsunami traces on the western and southern coastlines of the Peloponnesus (Greece), Earth Planet. Sci. Lett., 269, 271-279, 2008.

Scicchitano, G., Monaco, C., and Tortorici, L.: Large boulder deposits by tsunami waves along the Ionian coast of south-eastern Sicily (Italy), Mar. Geol., 238, 75-91, 2007.

Scicchitano, G., Costa, B., Di Stefano, A., Longhitano, S. G., and Monaco, C.: Tsunami and storm deposits preserved within a riatype rocky coastal setting (Siracusa, SE Sicily), Z. Geomorphol., Stuttgart, Mai, 54, Suppl. 3, 51-77, 2010.

Seymour, R. J.: Estimating wave generation on restricted fetches, J. Waterw. Port. C. Div, 103, 251-264, 1977.

Sgarrella, F. and Moncharmont Zei, M.: Benthic foraminifera of the Gulf of Naples (Italy): systematics and autoecology, Boll. Soc. Paleontol. It., 32, 145-264, 1993.

Smedile, A., De Martini, P. M., Pantosti, D., Bellucci, L., Del Carlo, P., Gasperini, L., Pirrotta, C., Polonia, A., and Boschi, E.: Possible tsunami signatures from an integrated study in the Augusta Bay offshore (Eastern Sicily-Italy), Mar. Geol., 281, 1-13, 2011.
Soloviev, S. L., Solovieva, O. N., Go, C. N., Kim, K. S., and Shchetnikov, N. A.: Tsunamis in the Mediterranean Sea 2000 B.C.2000 A.D., Advances in Natural and Technological Hazards Research, Kluwer Academic Publisher, 242 pp., 2000.

Stiros, S. C.: The AD 365 Crete earthquake and possible seismic clustering during the fourth to sixth centuries AD in the Eastern Mediterranean: a review of historical and archaeological data, J. Struct. Geol., 23, 545-562, 2001.

Stuiver, M. and Reimer, P. J.: Radiocarbon calibration program CALIB REV5.0.2, copyright, available at: http://calib.cub.ac.uk/ calib/ (last access: June 2011), 2005.

Stuiver, M., Reimer, P. J., and Braziunas, T. F.: High-precision radiocarbon age calibration for terrestrial and marine samples, Radiocarbon, 40, 1127-1151, 1998.

Sunamura, T. and Horikawa, K.: Two dimensional beach transformation due to waves, Proceedings 14th Coastal Engineering Conference, Am. Soc. Civ. Eng., 920-938, 1974.

Tinti, S., Maramai, A., and Graziani, L.: The Italian Tsunami Catalogue (ITC), Version 2, available at: http://www.ingv.it/servizi-e-risorse/BD/catalogo-tsunami/ catalogo-degli-tsunami-italiani (last access: May, 2011), 2007.

Tuttle, M. P., Ruffman, A., Anderson, T., and Jeter, H.: Distinguishing tsunami from storm deposits in eastern North America: The 1929 Grand Banks tsunami versus the 1991 Halloween storm, Seism. Res. Lett., 75, 117-131, 2004.

Vincent, C. L.: Deepwater wind wave growth with fetch and duration, Technical Reports num. CERCMP8413, Coastal Engineering Research Center Vicksburg Ms, 1984.

Vött, A., Brückner, H., May, S. M., Sakellariou, D., Nelle, O., Lang, F., Kapsimalis, V., Jahns, S., Herd, R., Handl, M., and Fountoulis, I.: The Lake Voulkaria (Akarnania, NW Greece) palaeoenvironmental archive e a sediment trap for multiple tsunami impact since the mid-Holocene, Z. Geomorph., N.F, Suppl., 53, 1-37, 2009.

Zhang, J. F. and Zhou L. P.: Optimization of the double SAR? procedure for polymineral fine grains, Radiat. Meas., 42, 14751482, 2007. 